\title{
Modelling temporal variability of in-situ soil water and vegetation isotopes reveals ecohydrological couplings in a willow plot
}

\author{
Aaron Smith ${ }^{1}$, Doerthe Tetzlaff ${ }^{1,2,3}$, Jessica Landgraf ${ }^{1}$, Maren Dubbert ${ }^{1,4}$, Chris Soulsby ${ }^{3,2,5}$ \\ ${ }^{1}$ IGB Leibniz Institute of Freshwater Ecology and Inland Fisheries Berlin, Berlin, Germany \\ $5 \quad{ }^{2}$ Humboldt University Berlin, Berlin, Germany \\ ${ }^{3}$ Northern Rivers Institute, School of Geosciences, University of Aberdeen, UK \\ ${ }^{4}$ ZALF Leibniz Center for Agricultural Landscape Research, Müncheberg, Germany \\ ${ }^{5}$ Technische Universitat Berlin, Institut für Bauingenieurwesen, Berlin, Germany
}

Correspondence to: Aaron Smith (smith@igb-berlin.de)

10 Abstract. The partitioning of water fluxes in the critical zone is of great interest due to the implications for understanding water cycling and quantifying water availability for various ecosystem services. We used the tracer-aided ecohydrological model $\mathrm{EcH}_{2} \mathrm{O}$-iso to evaluate water, energy, water stable isotope, and biomass dynamics at an intensively monitored study plot under two willow trees, a riparian species, in Berlin, Germany. Importantly, we assessed the value of in-situ soil and plant water isotope data to quantify xylem water sources and transit times, with coupled estimates of the temporal dynamics and ages of soil and root-uptake water. The willows showed high evapotranspiration water use, with limited percolation of summer precipitation to deeper soil layers due to the dominance of shallow root-uptake ( $>80 \%$ in the upper $10 \mathrm{~cm})$. Lower evapotranspiration under grass resulted in higher soil moisture storage, greater soil evaporation and more percolation of soil water. Biomass allocation was predominantly foliage growth (57\% in grass and $78 \%$ in willow). Shallow soil water age under grass was similar to under willows (15-17 days). Considering potential xylem transit times showed a large improvement in the model's capability to estimate xylem isotopic composition and water age, and revealed the high value of in-situ data within modelling. Root-uptake was predominately derived from summer precipitation events (56\%) and had an average age of 35 days, with xylem transport times taking at least $6.2-8.1$ days. By evaluating water partitioning, energy and isotope mass-balance, along with biomass allocation, the model revealed multifaceted capabilities for assessing water cycling within the critical zone at high temporal resolution, including xylem water sources and transport, which are all necessary for short and long-term assessment of water availability for plant growth.

\section{Introduction}

Understanding how water is partitioned in the Critical Zone $(\mathrm{CZ})$, the near-surface zone from the top of the vegetation canopy to groundwater (Grant and Dietrich, 2017), is essential for improving knowledge of landscape functionality while providing an evidence base for sustainable water management strategies. The partitioning of $\mathrm{CZ}$ water is strongly dependent on evapotranspiration (ET) (which accounts for $>60 \%$ of terrestrial precipitation) (Oki and Kanae, 2006; Zhang et al., 2016), 
https://doi.org/10.5194/bg-2021-278

Preprint. Discussion started: 4 November 2021

(c) Author(s) 2021. CC BY 4.0 License.

\section{(c) (i)}

with vegetation water use globally accounting for 65-70\% of evapotranspiration (Good et al., 2015; Jasechko et al., 2013). While measurements of ET and transpiration fluxes help to quantify water partitioning, these measurements usually do not constrain the dynamics of how water is taken from different water sources (i.e. different soil depths) which may greatly change with wetness conditions (Rothfuss and Javaux, 2017), climate zone (Amin et al., 2020), and seasonally (Barbeta and

35 Peñuelas, 2017). In regions such as the North European Plain, where ET dominates precipitation water partitioning (>90\%, UFZ (2021)), seasonal variations in ET greatly reduce water availability beyond vegetation uptake during the growing season. Additionally, the importance of evaluating the water footprint of biomass production in water-limited regions where ET is the dominant water flux highlights the importance of partitioning ET into its components of interception and soil evaporation and transpiration (Kool et al., 2014; Xiao et al., 2018). However, partitioning ET to quantify the transpiration component throughout the growing season is complicated by multiple factors including atmospheric demand, vegetation and root conductance, rooting distribution, stomatal resistance, and water potential throughout the soil profile (Dubbert and Werner, 2019; Jones and Tardieu, 1998; Sperry and Love, 2015). While total transpiration water usage may be constrained by direct measurement at small or larger scales (e.g. sap flow and eddy covariance, Kool et al. (2014)) the source of transpired water from the rooting zone throughout the growing season is not easily measured and remains highly uncertain

45 (Brantley et al., 2017; Dubbert and Werner, 2019).

Continued efforts to close the knowledge gap on root-uptake sources are essential as increasing climatic variability and accentuated extremes will likely affect crop and timber production (Lobell and Gourdji, 2012; Lobell et al., 2011) as well as groundwater and stream water availability (Gudmundsson et al., 2019; Taylor et al., 2013). Tracers in soils and xylem, specifically conservative water stable isotopes deuterium $\left({ }^{2} \mathrm{H}\right)$ and oxygen-18 $\left({ }^{18} \mathrm{O}\right)$, have previously been shown to be

50 effective tools to help constrain root-water uptake sources using various approaches (Rothfuss and Javaux, 2017). These approaches usually use mixing relationships; including linear mixing models of water derived from different pools (e.g. (Barbeta and Peñuelas, 2017)), the similarity of potential source waters and xylem water (e.g. ellipsoid method) (Amin et al., 2020; Tetzlaff et al., 2021), Bayesian mixing frameworks (cf. von Freyberg et al. (2020)), and physically-based modelling approaches (Knighton et al., 2020; Ogle et al., 2014; Sutanto et al., 2012). However, many of these previous studies have utilized data obtained from destructive sampling, which limits the number of samples and may not account for the transport lag of soil to xylem sample locations (von Freyberg et al., 2020), diurnal variability (De Deurwaerder et al., 2020), or stem internal storage and exchange with xylem (Steppe et al., 2006). Moreover, increasing uncertainty surrounds whether common destructive methods, which involve cryogenic extraction, actually represent xylem water (Allen and Kirchner, 2021; Chen et al., 2020). Recent developments of in-situ tracer measurements of soil and xylem (Marshall et al., 2020;

60 Oerter and Bowen, 2017) have broadened the possibilities for spatio-temporal evaluation of root-uptake distributions, in particular with physically-based modelling. Higher resolution sampling is beneficial as it can provide a wider range of temporal conditions (e.g. event rewetting) in which helps to increase confidence in model performance and in the assessment of model structure. 
https://doi.org/10.5194/bg-2021-278

Preprint. Discussion started: 4 November 2021

(c) Author(s) 2021. CC BY 4.0 License.

\section{(c) (i)}

Physically-based modelling approaches, such as ecohydrological models, have a wide range of applicability, including the estimation of fluxes and storages, flux partitioning, and biomass accumulation (Asbjornsen et al., 2011). Recent developments linking tracers into ecohydrological models (e.g. Kuppel et al. (2018a)) have further expanded the potential to track water flow paths and associated ages, which can aid in understanding water cycling and mixing within the CZ (Geris et al., 2017; Penna et al., 2018; Sprenger et al., 2019). Such modelling approaches can help overcome measurement limitations of isotopic data regarding temporal frequency and spatial heterogeneity which may affect estimates of water partitioning and source identification (Goldsmith et al., 2018; Rothfuss and Javaux, 2017; Sprenger and Allen, 2020). However, relatively few approaches have utilized physically-based models to estimate storage-flux-age dynamics while considering mixing of water after root-uptake (Knighton et al., 2020), particularly at high resolution, to account for sub-daily variability (e.g. De Deurwaerder et al. (2020)) or with consideration of root length properties (Gessler et al., 2021; Seeger and Weiler, 2021). Here, we utilized soil and xylem water isotope data from in-situ monitoring over the 2020 growing season in Berlin,

75 Germany, to calibrate a tracer-aided ecohydrological model and estimate flux and uptake dynamics. Importantly, we also used destructive methods to validate the in-situ data (Landgraf et al., 2021). The in-situ location, which also monitored soil moisture and vegetation growth dynamics, comprises a small stand of willow trees in a situation typical of NE Germany. The model, $\mathrm{EcH}_{2} \mathrm{O}$-iso, is a distributed physically-based model that couples water and energy fluxes, with vegetation carbon allocation across the soil-plant-atmosphere continuum (SPAC). The primary goal of this study was to evaluate the soil

80 storage-flux-age and vegetation uptake dynamics during the growing season by calibration across multiple data sets. This primary goal was achieved by: 1) assessing the partitioning of water usage and biomass dynamics and considering how well the tracer-aided ecohydrological model could reproduce in-situ measurements of fluxes, storages, and stable water isotopes; 2) exploring potential mixing dynamics of vegetation xylem water using sap flow and xylem isotopic composition; and 3) evaluating soil water ages and transit times of vegetation water. Such overall assessment of ecohydrological partitioning, in

85 fluxes as well as root-uptake, was intended to help to improve the conceptualization of water cycling in the $\mathrm{CZ}$ at hightemporal resolution, and contribute to an evidence base for management strategies in water sensitive areas.

\section{Study site and background}

\subsection{Study site}

The study site is in a peri-urban area, situated in the grounds of the Leibniz-Institute of Freshwater Ecology and Inland 90 Fisheries (IGB) in south-east Berlin (Fig 1b). The site is situated near Lake Muggelsee (80m north of the lake edge), encircled in the North and West by buildings (40m), and east and south (30 and 20m, respectively) by additional vegetation. A stream draining nearby fish retention ponds fringes the East of the study area. A lake water extraction facility (using bank filtration) is situated immediately north of the IGB site and groundwater is $\sim 2.2 \mathrm{~m}$ below the ground surface with limited annual variability $(<0.1 \mathrm{~m})$. A previous study at the site has excluded groundwater and the nearby stream water as likely sources of water to the trees (Landgraf et al., 2021). 

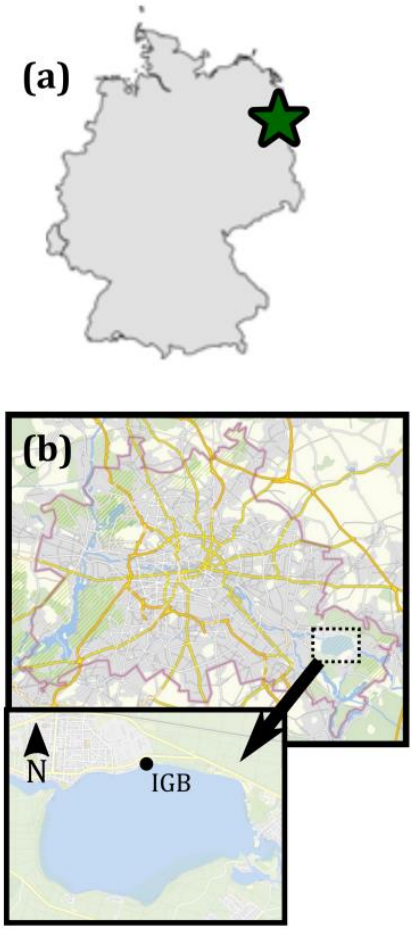

\section{(c)}

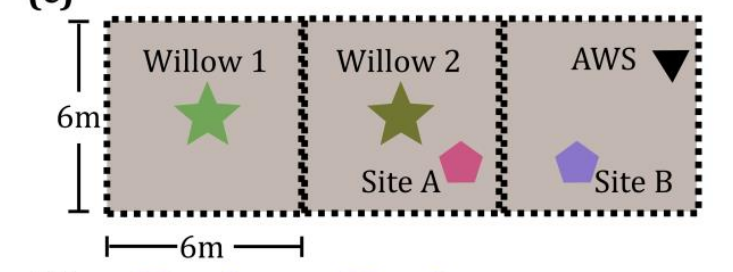

(d)

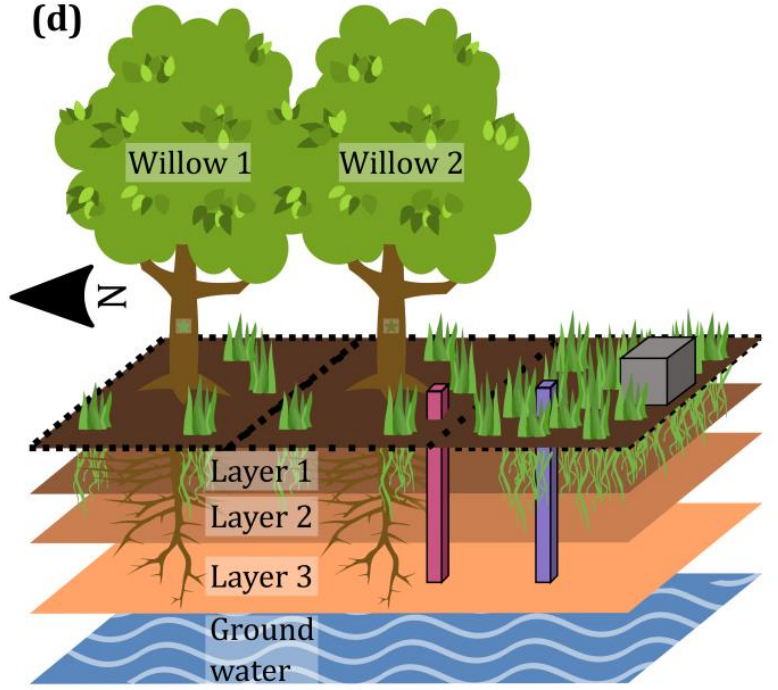

Figure 1: Study site location and site description. (a) Location of the site within Germany, (b) Location of IGB within Berlin (Berlin, 2021), (c) plan view of the study site including the location of willow trees, soil isotope and moisture, and automatic weather station (AWS), and (d) conceptual diagram of the study site, with three soil depths and two primary vegetation units (with relative prominence). Berlin Maps (C) OpenStreetMap contributors 2021. Distributed under the Open Data Commons Open Database License (ODbL) v1.0.

\subsection{Soils and vegetation}

The study site was chosen based on its open nature (not shaded) for the two willow trees (Salix alba) and an adjacent automatic weather station (Fig 1c\&d). Willows are a riparian species, which is well adapted to moderate and high moisture typical of riparian areas or with high groundwater levels (Isebrands and Richardson, 2014). Additional selection criteria for the study site is provided in Landgraf et al. (2021). The willows have a similar age of $\sim 15$ years with willow in the North (Willow 1, Fig 1c\&d) being slightly larger ( $\sim 9 \mathrm{~m}$ height and stem diameter: 398mm, 16.07.2020) and the southern willow (Willow 2, Fig 1c\&d) being slightly smaller ( $\sim 8 \mathrm{~m}$ height and stem diameter: $353 \mathrm{~mm}, 16.07 .2020)$. Sparse grass is present below the willow trees, with some bare soil patches (Fig. 1d). Grass coverage is greater with no clear bare soil patches in the open area south of the willows (Fig. 1d).

The site is situated in the North European Plain, with geology and surficial soils in the surrounding areas of Berlin deposited during the Weichselian glaciation (Deutschen Nationalkomitee, 2016). The willows are situated on reclaimed ground where 
https://doi.org/10.5194/bg-2021-278

Preprint. Discussion started: 4 November 2021

(c) Author(s) 2021. CC BY 4.0 License.

(c) (i)

a previous building was demolished and the site backfilled with sandy brown earth topsoil. Soil samples taken to $1 \mathrm{~m}$ depth reveal a relatively uniform soil structure, with a slightly higher organic horizon in the near-surface soils, which is more developed below the open grassland area south of the willows (Site B, Fig. 1c\&d).

\subsection{Climate}

The climate is continental with a maritime influence (Köppen Index) and experiences substantial interannual variability in precipitation (Table 1). The range of annual precipitation from within the climate normals (1980-2010) is $80 \%$ of the long term average precipitation (526 mm/year, Table 1) (DWD, 2021). While precipitation during the study period was similar to the climatic normal, the site experienced lower than normal humidity, and higher wind speeds and air temperature (Table 1). The growing season is less humid and is warmer than annual averages (Table 1), with large sub-daily variability hydroclimate. For the vegetation growing season in the surrounding region as well as Berlin, evapotranspiration (ET) is the dominant hydrologic flux, accounting for $\sim 90 \%$ of total precipitation (Gillefalk et al., 2021; Smith et al., 2020a).

125 Table 1: Climate conditions at a nearby long-term weather station, Berlin-Brandenburg airport (DWD, 2021). Average (standard deviation in parentheses) climate conditions are shown for the climate normals (1980 - 2010) and the study year (2020). The growing season is May - September (inclusive). NA is not applicable.

\begin{tabular}{|l|l|l|l|l|}
\hline & $\begin{array}{l}\text { Climate Normals } \\
(\mathbf{1 9 8 0}-\mathbf{2 0 1 0})\end{array}$ & $\begin{array}{l}\text { Study Year } \\
\mathbf{( 2 0 2 0})\end{array}$ & $\begin{array}{l}\text { Study Growing Daily Average High } \\
\text { Season (2020) }\end{array}$ & $\begin{array}{l}\text { Ad cow) in Growing } \\
\text { Season (2020) }\end{array}$ \\
\hline Precipitation (mm/year) & $526.5(104.5)$ & 529.1 & 257.1 & NA \\
\hline Relative Humidity (\%) & $76.8(2.1)$ & 71.9 & 64.2 & $90.5(42.9)$ \\
\hline Wind Speed $(2 \mathrm{~m}, \mathrm{~m} / \mathrm{s})$ & $3.10(0.2)$ & 3.5 & 2.9 & $5.0(1.0)$ \\
\hline Air Temperature $\left(2 \mathrm{~m},{ }^{\circ} \mathrm{C}\right)$ & $9.3(0.9)$ & 11.4 & 17.8 & $23.5(11.8)$ \\
\hline
\end{tabular}

\section{Materials and methods}

\subsection{In-situ measurements}

130 The study site was set up to continuously measure hydroclimate, soil moisture, and vegetation productivity. Hydrometeorological conditions at the site were monitored with a mobile Eddy Covariance system (Li-cor Biosciences, Lincoln, NE, USA), which included measurements of precipitation amounts (event), collection of precipitation samples for isotope analysis, humidity, air temperature, wind speed, short wave radiation, and latent heat. Climate data from the weather station were quality checked against nearby weather stations that have been in operation longer. These include measurements

135 from the roof of the nearby IGB building (2013), the station on Lake Muggelsee (2013), and surrounding DWD weather stations (DWD, 2021). Precipitation samples were collected at 4-hourly intervals. Each sample bottle was filled with $0.5 \mathrm{~cm}$ of paraffin oil to prevent evaporation. Precipitation samples were analysed with a Picarro L2130-i cavity ring-down laser spectrometer (Picarro, Inc., Santa Clara, CA, USA). 
https://doi.org/10.5194/bg-2021-278

Preprint. Discussion started: 4 November 2021

(c) Author(s) 2021. CC BY 4.0 License.

\section{(c) (i)}

Soil moisture, isotopes $\left(\delta^{2} \mathrm{H}\right.$ and $\left.\delta^{18} \mathrm{O}\right)$, and temperature were measured at two sites in the study area, Site A near Willow 2 and Site B in the open grass area. Soil moisture and temperature were measured at three depths $(10,40$, and $100 \mathrm{~cm})$ with water content reflectometers (CS616, Campbell Scientific, Inc. Logan, UT, USA) and thermistors (BetaTherm 100K6A1IA, Campbell Scientific, Inc. Logan, UT, USA). Soil isotope samples were collected using both destructive bulk soil sampling and with an in-situ vapour analyser. Installation of polypropylene membranes $(7 \mathrm{~cm}$ long) for soil water vapour extraction at three depths $(10,40$, and 100 cm) was conducted at the end of May 2020 (May 20, 2020). Extracted in-situ soil vapour samples were analysed every two hours using a Picarro L2130-I cavity ring down laser spectrometer (Picarro, Inc., Santa Clara, CA, USA), calibrated using the approach presented for this site in Landgraf et al. (2021).

To complement the climate and soil measurements, detailed measurements indicative of vegetation water fluxes and biomass accumulation were conducted continuously throughout the study period. Measurements included sap flow (heat ratio method, SFM1 instrument, ICT International, Australia), dendrometers (DR, Radius Dendrometer, Ecomaticl, Dachau, Germany), and xylem water vapour (Picarro, Inc., Santa Clara, CA, USA). Polypropylene membranes were installed in two bore holes in both willow trees starting in June (Willow 2). COVID-19 related complications delayed the installation in Willow 1 (August). Xylem water vapour was extracted from two bore holes on each willow tree, at $30 \mathrm{~cm}$ and $170 \mathrm{~cm}$, and analysed within the same analyser as the soil vapour isotopes every other hour. To prevent contamination of atmospheric air within the xylem vapour samples, the probe was embedded within the stem and sealed. Analyzed xylem water isotopes were evaluated for wounding effects (in early periods after installation) and any were removed from the analysis.

Heated cables were installed with the tubing for all vapour extraction to avoid condensation effects and modulate vapour temperatures. Additionally, tubing was flushed for 10 minutes if condensation was detected to remove any residual water. To test and correct for water concentration and temperature dependencies, a linear regression of vapour concentration and slopes of ${ }^{2} \mathrm{H}$ and ${ }^{18} \mathrm{O}$, and nonlinear regression of daily average xylem and soil isotopes with temperature (air and soil, respectively) was conducted to determine the strength of the relationship for water concentration and temperature-dependent offset. Corrected in-situ xylem and soil isotopes for water concentration and temperature were consistent with bulk soil isotope and twig cryogenically extracted isotope samples (see Landgraf et al. (2021) for more details).

\section{2 $\mathrm{EcH}_{2} \mathrm{O}$-iso model}

The $\mathrm{EcH}_{2} \mathrm{O}$-iso model is a physically-based, distributed, tracer-aided model coupling vegetation, and soil energy and water balance, and carbon utilization (Maneta and Silverman, 2013). The isotope module (simulating $\delta^{2} \mathrm{H}, \delta^{18} \mathrm{O}$, and water age) was coupled with the water balance to track the movement of water throughout the model domain (Kuppel et al., 2018a). The following section presents a brief synopsis of the model conceptualisation of energy, water, and isotope balances (conceptual diagram, Fig. S1). Further details of the model are provided in Maneta and Silverman (2013) and Kuppel et al. (2018a). 
https://doi.org/10.5194/bg-2021-278

Preprint. Discussion started: 4 November 2021

(c) Author(s) 2021. CC BY 4.0 License.

(c) (i)

\section{$170 \quad 3.2 .1 \mathrm{EcH}_{2} \mathrm{O}$-iso energy balance}

The energy balance is resolved with a top-down approach, conducting energy balance within the canopy before the energy balance at the surface. The canopy energy balance partitions incoming radiation into latent heat (interception evaporation and transpiration), sensible heat, and net radiation as a function of canopy temperature (Fig. S1). The canopy energy balance is very sensitive to the canopy stored water (maximum canopy storage parameter, $\mathrm{CWS}_{\max }$ ), where higher intercepted water

175 storage decreases energy availability for transpiration. Transpiration is limited by environmental constraints, implemented using a Jarvis-type stomatal conductance model dependent on soil moisture, vapour pressure deficit, air temperature, and incoming radiation. Plant hydraulics were incorporated using the Soil Plant Atmosphere Continuum module (SPAC) which tracks leaf water potential and conductivity limitations due to cavitation. The SPAC module includes supply-demand functions in the rhizosphere (as a function of soil hydraulic conductivity, root area index, and pore-disconnectedness index),

180 and stem and leaf (function of vegetation conductivity and leaf area index). The supply-demand further regulates transpiration by soil and vapour pressure deficits. To account for potential root-uptake from outside model cells containing vegetation, estimated radial rooting lengths (Section 3.3.1) were used to estimate the proportion of water used from adjacent cells.

The surface energy balance utilizes energy translated from the canopy energy balance to resolve latent heat (soil

185 evaporation), sensible heat, net radiation, ground heat, and snow and melt heat (only if snow is present) using surface temperature. Ground heat is resolved using two thermal layers, where the depth of the first thermal layer is defined as half of the depth where the thermal wave is damped by $37 \%$ (Arya, 2001).

\subsection{2 $\mathrm{EcH}_{2} \mathrm{O}$-iso water balance}

Similar to the energy balance, the water balance is estimated with a top-down approach including canopy, surface, and sub-

190 surface storage (Fig. S1). Canopy storage is estimated using a linear bucket approach, with maximum storage limited by a storage parameter $\left(\mathrm{CWS}_{\max }\right)$ and canopy interception driving draw-down of canopy storage. Net precipitation as throughfall accumulates on the soil surface (ponded water) and infiltrates into the shallow soil (layer 1) using the Green-Ampt model (Brooks-Corey, air-entry pressure, and vertical hydraulic conductivity parameters, $\lambda_{\mathrm{BC}}, \psi_{\mathrm{ae}}$, and $\mathrm{K}_{\mathrm{v}}$, respectively). Ponded water at the end of each time-step is directly routed to ponded water in the next downstream cell. Soil water redistribution is

195 conducted using gravitational drainage when field capacity is exceeded. Redistribution is estimated for each model layer. Very dry soils at the study site prompted the introduction of sub-discretization of shallow soils (layer 1) to estimate the moisture at discrete depths in addition to the average moisture of the layer. Shallow soils were sub-discretized into $1 \mathrm{~cm}$ increments with incoming water (infiltration and return flow) entering from the layer boundaries and redistributed using gravitational drainage. Sub-discretization was implemented for informational purposes only, not for use in calibration.

200 Gravitational drainage rates linearly increase from zero (at field capacity) to saturated vertical conductivity when the soil is fully saturated. Upward redistribution of water occurs if deeper soil storages are fully saturated. Vertical downward flux 
https://doi.org/10.5194/bg-2021-278

Preprint. Discussion started: 4 November 2021

(c) Author(s) 2021. CC BY 4.0 License.

\section{(c) (i)}

from the deepest soil layer (layer 3) can occur due to leakance out of the model domain. Lateral flow may occur in the deepest soil layer, with water above field capacity routed to the next downstream model cell using a linear kinematic wave model.

\subsection{3 $\mathrm{EcH}_{2} \mathrm{O}$-iso isotope mixing and water ages}

$\mathrm{EcH}_{2} \mathrm{O}$-iso estimates isotopes $\left(\delta^{2} \mathrm{H}\right.$ and $\left.\delta^{18} \mathrm{O}\right)$ and water age for each storage using a complete mixing assumption (fully mixed at the end of each time-step). In storage, mixing is conducted with amount weighted-averaging of isotopic compositions (or age) with incoming fluxes. Out-fluxes have the same isotopic composition (and age) as the mixed water in storage. Evaporative fractionation is estimated for the shallow soils (layer 1) using estimated soil evaporation and the CraigGordon fractionation model (Craig and Gordon, 1965). Humidity in the soil is estimated using the method proposed by Lee and Pielke (1992), with the kinetic fractionation factor modified for use in soils (Braud et al., 2005). Isotopic composition and water ages of transpired water are estimated by amount weighting the contribution of root-uptake from each soil layer (root-uptake proportion dependent on water availability and rooting distribution). The amount-weighting assumes instant mixing of soil water within the vegetation and encompasses no mixing of previous soil isotopes or water ages. At the end of each time-step the age of water in storage is advanced by one time-step.

To evaluate the distribution of water ages, calibrated simulations were re-run for each time-step that included a precipitation event (925 hours with precipitation over the study period). For each of the 100 'best' simulations, the input precipitation concentration was changed in a stepwise manner with a concentration of " 1 " on the precipitation event evaluated. For example, the $25^{\text {th }}$ precipitation event (i.e. $25^{\text {th }}$ hour with precipitation, here, January $7^{\text {th }}, 11: 00 \mathrm{am}$ ), the precipitation concentration was set to 1 while all other precipitation and initial storages had concentration of 0 . The concentration was tracked through the domain to provide a proportion of water in each storage originating from the precipitation event. The cumulative concentration of different precipitation events sums to 1 when all of the water in storage is younger than the duration of the simulation.

\subsection{Tree water mixing and transit times}

225 Knighton et al. (2020) showed that improved estimation of xylem isotopes could result when considering potential vegetation storage, and mixing of soil water older than one time-step within $\mathrm{EcH}_{2} \mathrm{O}$-iso. Similarly, Seeger and Weiler (2021) showed promising conceptualization of isotope mixing within vegetation based on a convolution approach using in-situ measurements. To evaluate the dynamics of transit times in xylem during the study period, a combination of modelled results (sap flow and soil isotopes) and assumed vegetation root distributions were used to estimate vegetation xylem water composition and age at the average measurement height $(1 \mathrm{~m})$ while accounting for spatial variability of soil water isotopes (laterally and with depth). The tree water mixing routine (applied post- $\mathrm{EcH}_{2} \mathrm{O}$-iso calibration) was developed with the assumption that isotopic mixing is dependent on the rooting distance (cf. Seeger and Weiler (2021)) and using the convolution equation to mix water from different pools (e.g. outside model cell or different soil layers). This differs from the 
https://doi.org/10.5194/bg-2021-278

Preprint. Discussion started: 4 November 2021

(c) Author(s) 2021. CC BY 4.0 License.

(c) (i)

traditional approach currently utilized in $\mathrm{EcH}_{2} \mathrm{O}$-iso which instantly mixes uptake-water throughout the tree. Hereafter, the new xylem mixing will be referred to as distance-based mixing, and the method used internally by $\mathrm{EcH}_{2} \mathrm{O}$-iso is referred to as instantaneous mixing.

\subsubsection{Vertical and radial rooting length}

The average vertical and horizontal distances (and total distance) of roots in each layer to the measurement height were estimated using a modification of the root depth and radial spread approach used in Sperry et al. (2016). The parameterization of this approach is in synchrony with the rooting distribution and SPAC module within $\mathrm{EcH}_{2} \mathrm{O}$-iso. Following $\mathrm{EcH}_{2} \mathrm{O}$-iso, the rooting distribution $\left(\mathrm{k}_{\mathrm{root}}\right)$ was used to determine the proportion of total roots in each soil layer (Kuppel et al., 2018b). Vertical distances (v) from the base of the vegetation to the vertical centre of the biomass in each layer were estimated using a $\log$ function of rooting proportions (Sperry et al., 2016):

$v(i)=0.01 * \ln \left(1-0.995 *\left(P(i)-\frac{(P(i)-P(i-1))}{2}\right)\right) / \ln \beta$

245 where $i$ is the soil layer, $\mathrm{p}$ is the cumulative proportion of roots (from the surface) and $\beta$ is a rooting distribution parameter $\left(\beta=-0.0089 * k_{\text {root }}+0.9947\right)$. The radial distance from the stem of the vegetation is estimated as a function of the volume of rooting (Sperry et al., 2016):

$\mathrm{Vol}=d_{1} * \pi *(D * a)^{2}$

where $\mathrm{Vol}$ is the volume of roots in layer $1, d_{1}$ is the depth of layer 1, $D$ is the total depth of the soil, and $a$ is an aspect parameter, controlling radial distance. The radial distance is then estimated as:

$r(i)=\left(3 * \operatorname{Vol} * \frac{p(i)}{d(i) * \pi}\right)^{0.5}$

where $r(i)$ is the average radial distance in layer $i, p$ is the proportion of roots in layer $i$ estimated from $\mathrm{k}_{\text {root }}$, and $d$ is the depth of layer $i$ (Fig. 2a). The total average distance $(D(i))$ for roots in each layer is the sum of $v(i)$ and $r(i)$. The radial extent of roots in each layer is then used to estimate the proportion of roots within the cell and in adjacent cells.

\subsubsection{Xylem transit time, and calibration}

Since much of the root systems below trees are not well characterized, including limited information on the proportion or total lengths of fine roots to transport roots are available, and the translation of xylem velocity to fine root velocity, we simplified the conceptualization of root transport for each soil layer into convolution integrals (Rothfuss and Javaux, 2017). We conceptualize the rooting system in each soil layer similar to a large river (primary root transport) network with many tributaries (fine roots) with precipitation input (root uptake volume). In this way, root water velocity is indirectly accounted (averaged) across different root diameters. Root-uptake volume weighted (estimated from $\mathrm{EcH}_{2} \mathrm{O}$-iso, Fig. 2c) convolution equations (gamma distribution) were used to estimate xylem $\delta^{2} \mathrm{H}$ from each soil layer for each hourly time-step (Fig. 2d). The approach introduces a scale parameter ( $\beta$, hours) for each soil layer and one shape parameter $(\alpha)$ as a function of total 
https://doi.org/10.5194/bg-2021-278

Preprint. Discussion started: 4 November 2021

(c) Author(s) 2021. CC BY 4.0 License.

root length (four total parameters) (Fig. 2b). This approach assumes that there is no cavitation (no drought conditions) within the xylem or roots of the plant.

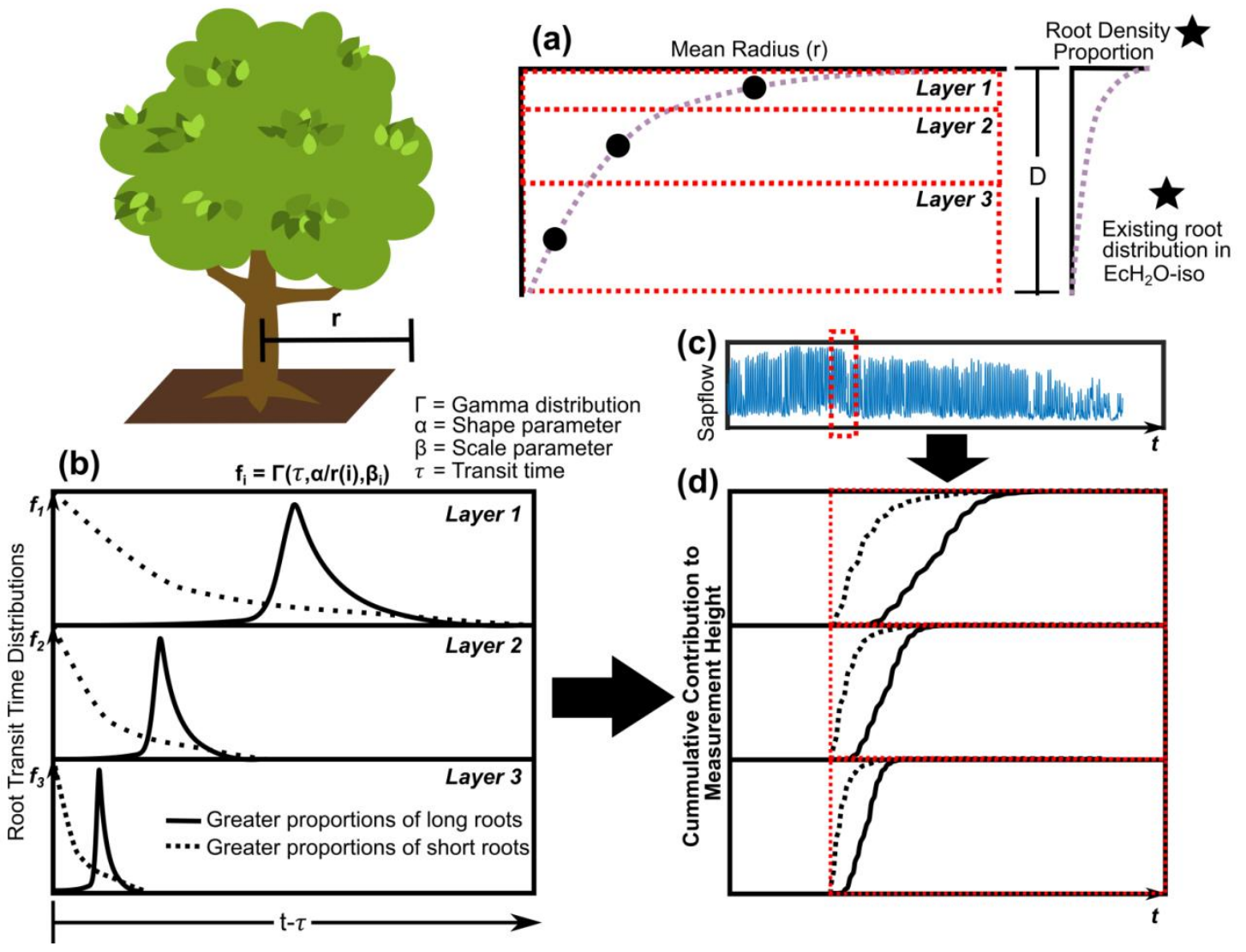

Figure 2: The estimation of rooting density (a) vertically and (b) the transit time distribution describing root velocity and distance to measurement height weighted by (c) sap flow to get the (d) cumulative contribution of soil water from entry time (red line).

To evaluate and test the information content of sampling frequency, the convolution integral was calibrated against xylem isotopes at different time-step intervals: using 6, 12, and 24-hour intervals. Measured and simulated xylem isotopes were averaged over the respective intervals prior to evaluation with the Kling-Gupta efficiency (Kling et al., 2012). While not used in calibration, the KGE of standardized hourly xylem was evaluated to examine how well sub-daily dynamics of soil isotopes propagated through the roots. Lastly, to evaluate the effectiveness of distance-based and instantaneous mixing, the transit time and xylem isotopes were calibrated twice, 1) using modelled soil isotopic compositions and sap flow, and 2) using measured soil isotopes and sap flow. The use of measured soil isotopes and sap flow tests the maximum potential for how each model performs and is not limited to the performance of $\mathrm{EcH}_{2} \mathrm{O}$-iso for sap flow or soil isotope. Further, the twin calibration approach shows how the error in simulation soil isotopes potentially propagates through to the estimation of xylem isotope and transit time mixing. Both xylem isotope model calibrations used the root-water uptake proportions estimated from the multi-criteria $\mathrm{EcH}_{2} \mathrm{O}$-iso calibration (Section 3.4). The Akaike information criteria (AIC, Akaike (1998)) 
https://doi.org/10.5194/bg-2021-278

Preprint. Discussion started: 4 November 2021

(c) Author(s) 2021. CC BY 4.0 License.

\section{(c) (i)}

280 was used to assess the significance of the additional parameters used by the distance-based mixing (4 additional parameters). The AIC is estimated using the log-likelihood of each model fit and number of parameters, where lower AIC indicates better model performance.

\section{4 $\mathrm{EcH}_{2} \mathrm{O}$-iso and tree mixing model calibration and set-up}

\subsubsection{Model set-up}

285 To best account for measurements in both willows and the soil moisture measurement locations, the model was set up with three square grids $(6 \mathrm{~m})$. Two grids contained one willow each and the third contained the open grass area (Fig. 1c). The model was set up to run with hourly time-steps between January 1, 2020, and October 31, 2020, encompassing a spin-up and the primary growing season. Soil layer depths were fixed at the depth of the soil moisture measurements $(10,40$, and $100 \mathrm{~cm})$ for all model cells. Further, previous analysis suggests that primary water sources of the willow trees were within the upper

$290100 \mathrm{~cm}$ of the soil, with little isotopic evidence of trees using water with distinct groundwater or stream water signatures, despite their proximity (Landgraf et al., 2021). The low local measured soil moisture and high transpiration in the willows suggests notable water use from outside the measurement location (model cell), and therefore parameterization of rooting radius (aspect parameter) was set to result in water being available from outside the cell. Due to the notable differences in shallow soil moisture between Site A and B (organic content), soil parameters were different below the willows and the open

295 grass (see calibrated parameters, Table S1). Initial soil moisture was set to field capacity which was revealed by model testing to have negligible influence on soil moisture simulations during the growing season. Soil isotopes were initialized using the average measured isotopes. Initial soil isotopes for the shallowest soils were not sensitive as simulated isotopes stabilized prior to the beginning of measurement (end of May 2020). The basal diameter of the willows was set to the measured diameter at the start of monitoring.

\subsubsection{Model forcing data, calibration and evaluation}

Hourly model forcing data primarily consisted of data measured with the mobile weather station at the study site (Section 3.1) corrected and gap-filled (where necessary) using the surrounding weather stations (Fig. S2). As long-wave radiation was not measured, estimated long-wave radiation was used from the ERA5 reanalysis dataset (Hersbach et al., 2020) (Table 2). To best constrain the model performance, and provide an evaluation of how well the model estimates the dynamics of water,

305 tracer, and energy fluxes during the growing season, all available data (except $\delta^{18} \mathrm{O}$ ) were used to constrain model parameterization. To simplify the presentation of results, we present $\delta^{2} \mathrm{H}$ as the results were not greatly different from $\delta^{18} \mathrm{O}$. Furthermore, the evaluation of a single growing season at the site limits the feasibility of a split calibration approach. To simultaneously evaluate the variability, bias, and correlation of the measured and simulated datasets, the KGE was used for multicriteria calibration of all datasets. Step-wise calibration was utilized to calibrate tracer, energy, and water balance, 310 followed by biomass (leaf area index and basal area). With no direct measurements of LAI in the grass site, MODIS (Myneni 
https://doi.org/10.5194/bg-2021-278

Preprint. Discussion started: 4 November 2021

(c) Author(s) 2021. CC BY 4.0 License.

et al., 2015) dynamics (modified range with maximum LAI $=2$ ) were used to calibrate the LAI. Each calibration utilized 100,000 Latin Hypercube Sample parameter sets, with parameter combination feasibility evaluated prior to simulations. Infeasible parameter combinations were rejected and resampled from parameter space. An empirical cumulative distribution function (eCDF) was created for each output. For each parameter set, the minimum eCDF value for all variables was used to rank the simulations, retaining the 100 "best" simulations for analysis.

Table 2: Forcing and calibration data $\mathrm{EcH}_{2} \mathrm{O}$-iso calibration.

\begin{tabular}{|l|l|l|l|l|}
\hline Forcing Data & Calibration Data \\
\hline & $\begin{array}{l}\text { Temporal } \\
\text { Resolution }\end{array}$ & \multicolumn{1}{l|}{$\begin{array}{l}\text { Temporal } \\
\text { Resolution }\end{array}$} & Efficiency \\
\hline Precipitation & Hourly & $\begin{array}{l}\text { Soil Moisture }(10,40,100 \mathrm{~cm} ; \\
\text { Site A\&B) }\end{array}$ & Hourly & KGE \\
\hline Precipitation Isotopes & $4-$ Sour & $\begin{array}{l}\text { Soil } \delta^{2} \mathrm{H}(10,40,100 \mathrm{~cm} \text {; Site } \\
\text { A\&B) }\end{array}$ & Daily & KGE \\
\hline Air Temperature & Hourly & Surface Temperature (Site B) & Hourly & KGE \\
\hline Relative Humidity & Hourly & Latent Heat (Site B) & Hourly & KGE \\
\hline Wind Speed & Hourly & $\begin{array}{l}\text { Leaf Area Index (Grass \& } \\
\text { Willow 2) }\end{array}$ & Daily & KGE \\
\hline Shortwave Radiation & Hourly & Basal Area (Willow 1\&2) & Daily & KGE \\
\hline Longwave Radiation & Hourly & Sap flow (Willow 1) & Daily & KGE \\
\hline
\end{tabular}

\section{Results}

\section{1 $\mathrm{EcH}_{2} \mathrm{O}$-iso soil water, isotope and energy balance evaluation}

Model calibration provided adequate simulations of each calibration variable. Similar to measured data, simulations of soil moisture and soil isotopes showed decreasing dynamics with increasing depth from the surface (Fig. 3). Despite the close proximity, Site A and B had largely different soil moisture and isotopic response in the upper soils (Fig. 3a-d). Simulations were able to capture the drier soil moisture in Site A relative to Site B (Fig. 3a\&c); however, the simulated dynamics of average moisture in layer 1 were greater than the measured moisture at $10 \mathrm{~cm}$ likely due to greater moisture retention in the organic material near the surface preventing infiltration reaching $10 \mathrm{~cm}$. Sub-discretization of the shallow layer 1 soil using calibrated parameters revealed that while average moisture in the upper $10 \mathrm{~cm}$ is high (blue lines, Fig. 3a), percolation of infiltrated water down to $10 \mathrm{~cm}$ during the summer months is limited (Fig. 3a, red line). Late season soil moistures (average and at $10 \mathrm{~cm}$ ) were over-estimated relative to measurements, coinciding with the underestimation of sap flux during the same period (Fig. 4).

330 The general dynamics of the soil isotopes at $10 \mathrm{~cm}$ in Site A was reasonably represented, however the larger variability during a period of depletion in August was not captured. Soil moisture and isotope dynamics in the deeper soils $(40 \mathrm{~cm})$ were much more damped than $10 \mathrm{~cm}$, with a slight under-estimation bias in $40 \mathrm{~cm}$ at Site B despite appropriate dynamics (Fig. 3d). The much lower variability of isotopes and soil moisture at $100 \mathrm{~cm}$ was similarly captured by the model calibration. The 
https://doi.org/10.5194/bg-2021-278

Preprint. Discussion started: 4 November 2021

(c) Author(s) 2021. CC BY 4.0 License.

higher depletion simulated at Site A relative to measured was consistent with the deeper $(100 \mathrm{~cm})$ soil isotopes measured at

Site B. Outliers of in-situ soil isotopes towards the end of the growing season (end of August and September, Fig. 3c-f) were a result of rapid temperature changes which were too marked for the system (i.e. heated cables) to control and caused temporary condensation effects in the tubing. These data were few and did not have notable effect on the soil isotope investigation.
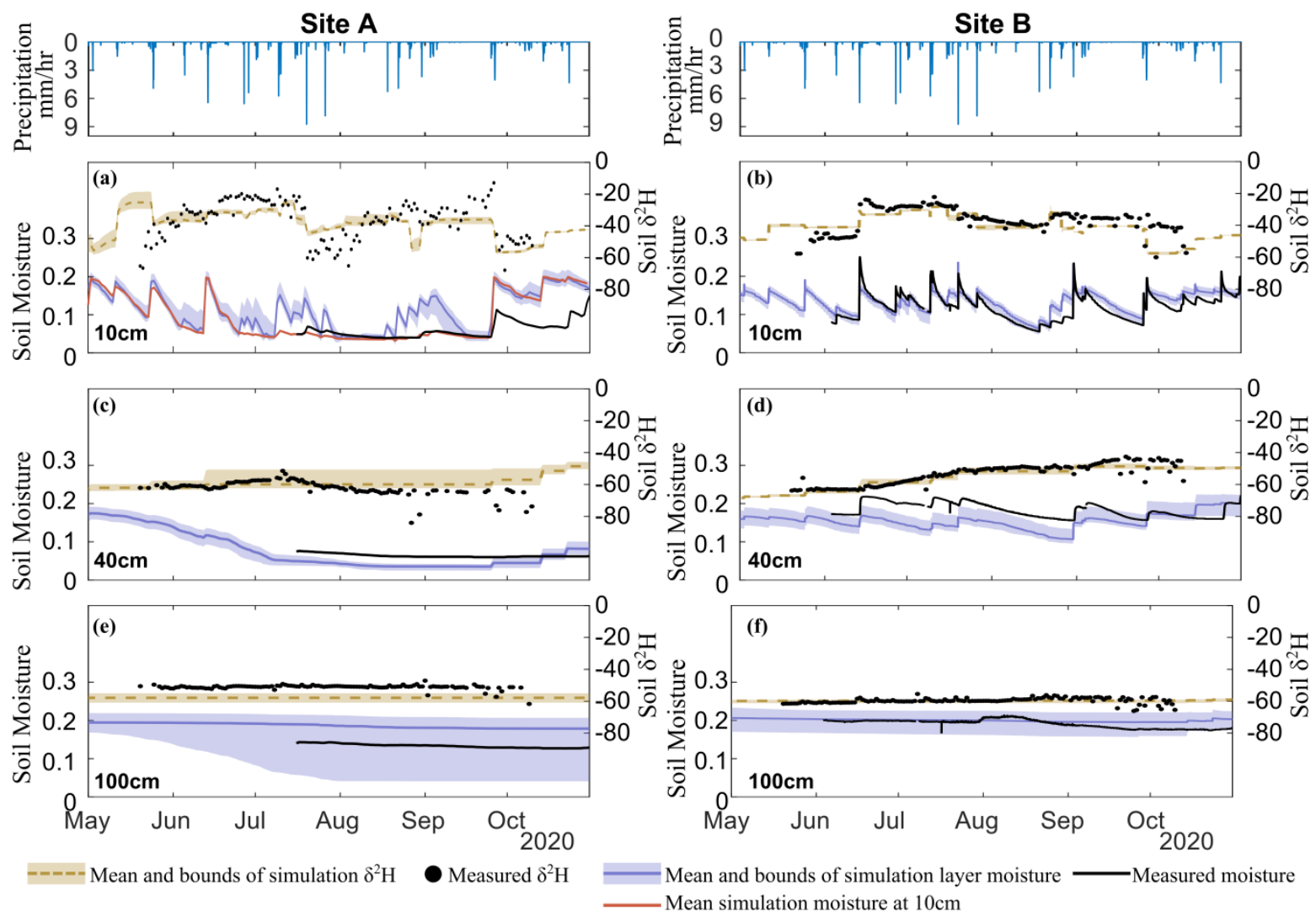

---- Mean and bounds of simulation $\delta^{2} \mathrm{H}$

Measured $\delta^{2} \mathrm{H}$

340 Figure 3: Simulation mean and upper and lower bounds of soil moisture and $\delta^{2} H$ in Site $A$ at (a) $10 \mathrm{~cm}$, (c) $40 \mathrm{~cm}$, and (e) $100 \mathrm{~cm}$, and at Site $B$ at $(\mathrm{b}) 10 \mathrm{~cm},(\mathrm{~d}) 40 \mathrm{~cm}$, and (f) $100 \mathrm{~cm}$. The top row shows the hourly precipitation for both sites.

Estimated energy balance (latent heat, sensible heat, transpiration flux, and temperature) were additionally shown to match in-situ measurements quite well (Fig. 4). Despite only utilizing latent heat and surface temperature at Site B in the calibration, simulated sensible heat and soil temperature at multiple depths were additionally reasonably captured. Latent heat and sensible heat at Site A (Willow 2) were notably more variable than at Site B, driven by the greater transpiration demands of the Willow relative to the grasses. Sap flux in the willow was adequately captured by the model, with only the late season (Sept - Oct) showing under-estimation relative to measurements. Greater variability of surface and soil $(10 \mathrm{~cm})$ temperature was additionally simulated at Site A; however, estimated differences in ground heat storage between Site A and $\mathrm{B}$ resulted in increased damping of soil temperature with depth at Site A. Progressive over-estimation of the soil temperature 
https://doi.org/10.5194/bg-2021-278

Preprint. Discussion started: 4 November 2021

(c) Author(s) 2021. CC BY 4.0 License.

350 during the early simulation period with increasing soil depth is likely due to propagation of a slight over-estimation of earlygrowing season surface temperature at each site (Fig. 4) potentially due to lower estimated leaf area index at the beginning of the growing season (Fig. 5).
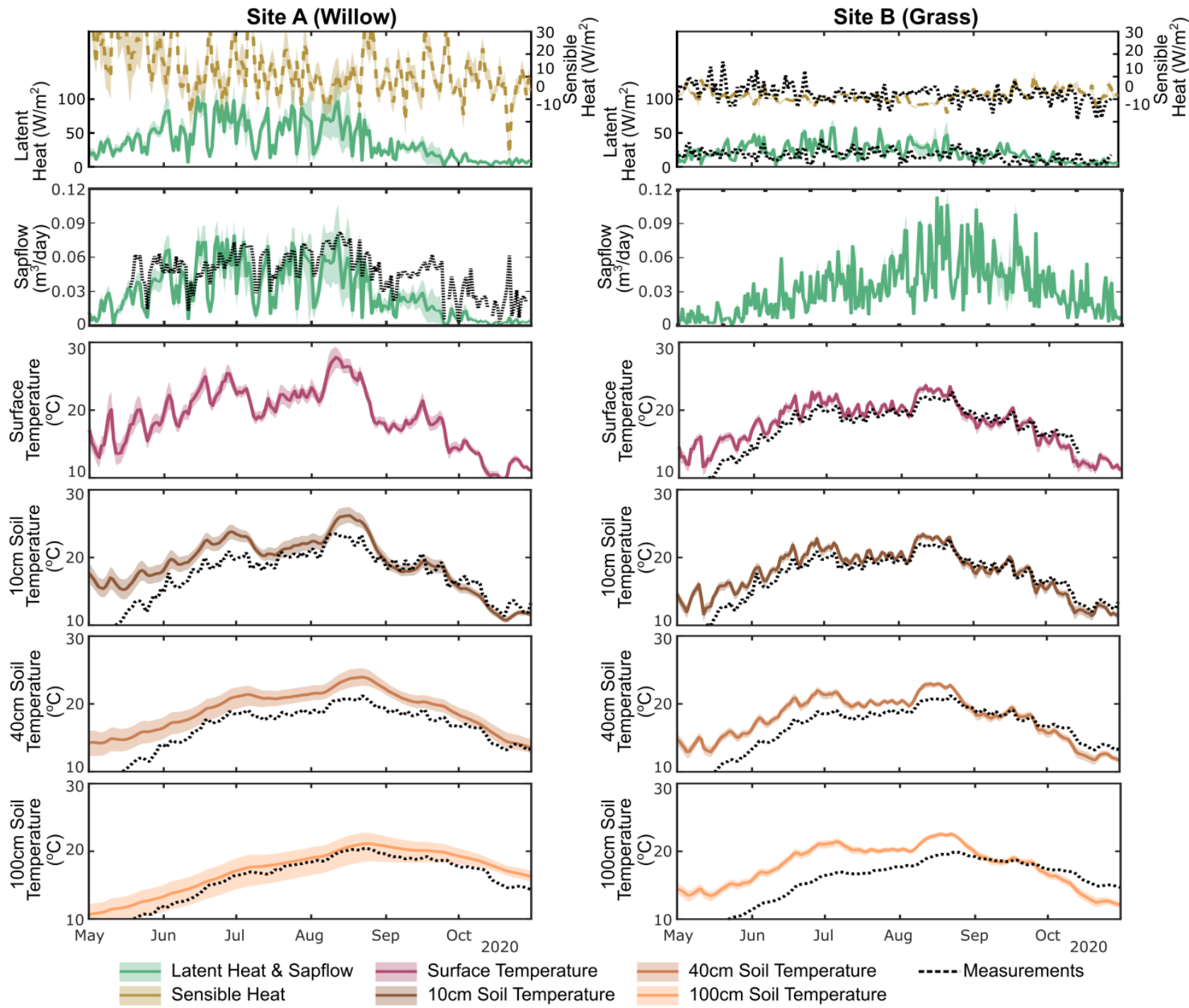

Figure 4: Simulation mean and upper and lower bounds of energy balance components of latent and sensible heat, and surface and soil temperature at multiple depths. Black dashed lines show the mean of measured data. Note: soil temperature was not calibrated.

\subsection{Growing season dynamics - fluxes and biomass accumulation}

Simulated biomass for foliage and tree diameter produced reasonable results for the two willow trees throughout the simulation period, with only minor deviations from both measured and remote sensed (MODIS) datasets (Fig. 5a\&b). 
https://doi.org/10.5194/bg-2021-278

Preprint. Discussion started: 4 November 2021

(c) Author(s) 2021. CC BY 4.0 License.

(c) (i)

Average simulations (solid lines) under-estimated LAI at the beginning of the growing season; however, these difference were relatively small and uncertainty bounds of simulated LAI were within measurement uncertainty. Calibrated grass leaf area index dynamics were consistent with MODIS, with only a small deviation in leaf area index at the beginning of the growing season (Fig. 5c). The dynamics and total net stem growth was adequately captured by the model for each willow; however, there was a slight underestimation of average net growth in Willow 2 (Fig. 5c\&d).
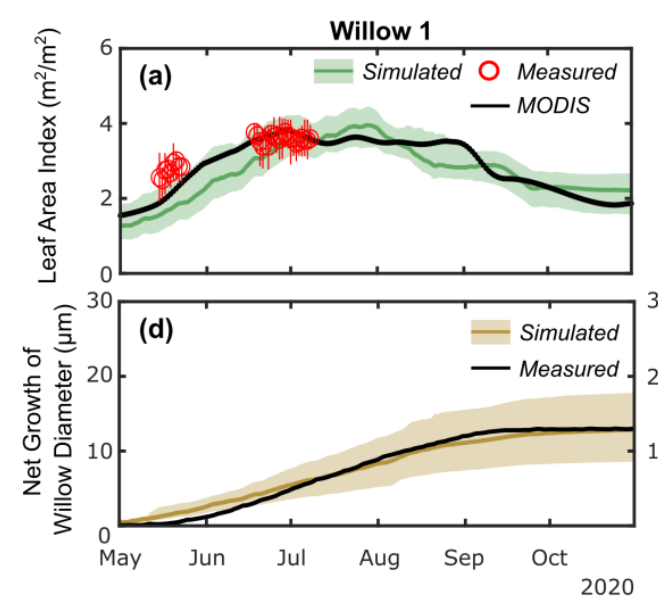
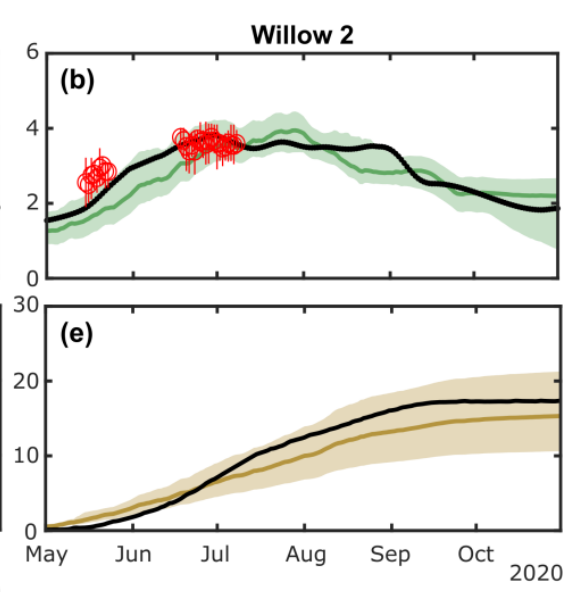

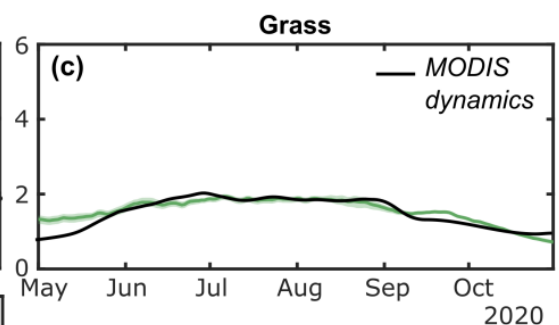

Figure 5: Simulated and measured leaf area index of (a) Willow 1, (b) Willow 2, and (c) Grass, and net growth of willow diameter of (d) Willow 1, and (e) Willow 2.

Modelled partitioning of water fluxes and biomass allocation in the willow and grass sites showed marked differences despite the relative proximity. Evapotranspiration (ET) dominated water partitioning throughout the summer, with the greatest ET between June 15 and September 15. Total ET was dominated by transpiration $\left(T_{r}\right)$ particularly for the willows $(>70 \%)$. This coincided with a decreased interception evaporation $\left(\mathrm{E}_{\mathrm{i}}\right)$ and soil evaporation $\left(\mathrm{E}_{\mathrm{s}}\right)$ proportions from drier soils. Pre-growing season infiltration was higher below the willows relative to the grass, with moderately lower infiltration below the willows during the growing season. The lower density of grass coverage (and increased bare soil) below the willow reduced growing season difference in infiltration between the willow and grass sites. The high root uptake rate of the willow resulted in negligible percolation of water to deeper soil layers during the growing season. Continuation of drier conditions below the willow resulted in a gradual shift toward near-surface root-uptake compared to a higher proportion (24\%) from deeper soils at the beginning of the growing season (Table 3). The willows showed little change in biomass allocation with only slight shift of root growth in the pre-growing season to foliage growth during peak growing season (Table 3). Allocation to stem growth showed negligible change throughout the growing season.

380 The grasses had much higher percolation to deeper soils relative to the willows as a result of low ET. Wetter soils below the grasses resulted in greater soil evaporation proportions. Higher soil moisture throughout the soil profile resulted in more stable root-uptake proportions from layers 1 and 2, with an approximately equal mixture of near-surface and mid-depth 
https://doi.org/10.5194/bg-2021-278

Preprint. Discussion started: 4 November 2021

(c) Author(s) 2021. CC BY 4.0 License.

$(40 \mathrm{~cm})$ soil water. Biomass allocation in grasses was static throughout the simulation (as a result of EcH $\mathrm{O}_{2} \mathrm{O}^{\mathrm{s}} \mathrm{structure}$ ), showing a greater allocation of carbon to foliage growth than roots (note there is no allocation to stem growth).

Table 3: Mean (and standard deviation) of water partitioning before (Jan -May), during early growing season (May 1 - June 15), mid growing season (June 16 - Aug 1), and late growing season (Aug 1 - Oct 31). Also shown are the root-uptake (RU) proportions from each soil layer (L1, L2, L3 are layer 1, 2, and 3, respectively) and biomass allocations. Depth of the L1, L2, and L3 are 0-10, $10-40$, and $40-100 \mathrm{~cm}$, respectively. Note that infiltration and percolation are cell averages, ET is specific to vegetation (proportion of willow in cell $<\mathbf{1 0 0 \%}$ ). ET is evapotranspiration, Es is soil evaporation, $\mathbf{T r}$, is transpiration, and Ei is interception evaporation.

\begin{tabular}{|c|c|c|c|c|c|c|}
\hline & \multicolumn{6}{|c|}{ Fluxes } \\
\hline & \multicolumn{3}{|c|}{ Willow } & \multicolumn{3}{|c|}{ Grass } \\
\hline & $\begin{array}{l}\text { Infiltration } \\
(\mathrm{mm})\end{array}$ & $\begin{array}{l}\text { Percolation } \\
(\mathrm{L} 1 \rightarrow \quad \text { L2) } \\
(\mathrm{mm})\end{array}$ & $\mathrm{ET}(\mathrm{mm})$ & $\begin{array}{l}\text { Infiltration } \\
(\mathrm{mm})\end{array}$ & $\begin{array}{l}\text { Percolation } \\
(\mathrm{L} 1 \rightarrow \quad \text { L2) } \\
(\mathrm{mm})\end{array}$ & $\mathrm{ET}(\mathrm{mm})$ \\
\hline Jan - May & $173.4 \pm 2.6$ & $127.1 \pm 4.9$ & $76.9 \pm 7.6$ & $168.4 \pm 1.4$ & $128.3 \pm 1.0$ & $86.5 \pm 1.9$ \\
\hline May $1-$ June 15 & $44.3 \pm 1.5$ & $4.3 \pm 2.9$ & $87.8 \pm 6.8$ & $46.6 \pm 0.8$ & $16.1 \pm 1.4$ & $62.0 \pm 1.5$ \\
\hline June $16-$ Aug 1 & $42.9 \pm 2.6$ & $0 \pm 0$ & $136 \pm 11.3$ & $49.8 \pm 1.3$ & $15.6 \pm 1.2$ & $87.8 \pm 1.7$ \\
\hline Aug $1-$ Sept 15 & $28.8 \pm 1.7$ & $0 \pm 0$ & $95 \pm 11.1$ & $43.6 \pm 0.9$ & $21.0 \pm 0.7$ & $62.0 \pm 2.3$ \\
\hline \multirow{3}{*}{ Sept $16-$ Oct 31} & $41.7 \pm 1.4$ & $15.2 \pm 2$ & $35.2 \pm 3.9$ & $48.2 \pm 0.5$ & $28.1 \pm 0.5$ & $34.7 \pm 0.8$ \\
\hline & \multicolumn{6}{|c|}{ Evapotranspiration Fractions } \\
\hline & $\mathrm{E}_{\mathrm{s}} / \mathrm{ET}$ & $\mathrm{T}_{\mathrm{r}} / \mathrm{ET}$ & $\mathrm{E}_{\mathrm{i}} / \mathrm{ET}$ & $\mathrm{E}_{\mathrm{S}} / \mathrm{ET}$ & $\mathrm{T}_{\mathrm{r}} / \mathrm{ET}$ & $\mathrm{E}_{\mathrm{i}} / \mathrm{ET}$ \\
\hline Jan - May & $0.3 \pm 0.05$ & $0.33 \pm 0.03$ & $0.37 \pm 0.05$ & $0.29 \pm 0.01$ & $0.34 \pm 0.02$ & $0.37 \pm 0.02$ \\
\hline May 1 - June 15 & $0.1 \pm 0.02$ & $0.7 \pm 0.03$ & $0.2 \pm 0.02$ & $0.23 \pm 0.01$ & $0.54 \pm 0.02$ & $0.23 \pm 0.01$ \\
\hline June $16-$ Aug 1 & $0.01 \pm 0$ & $0.77 \pm 0.03$ & $0.21 \pm 0.02$ & $0.17 \pm 0.01$ & $0.52 \pm 0.02$ & $0.31 \pm 0.02$ \\
\hline Aug $1-$ Sept 15 & $0.01 \pm 0$ & $0.78 \pm 0.03$ & $0.21 \pm 0.03$ & $0.16 \pm 0.01$ & $0.55 \pm 0.02$ & $0.29 \pm 0.02$ \\
\hline \multirow[t]{3}{*}{ Sept $16-$ Oct 31} & $0.12 \pm 0.03$ & $0.4 \pm 0.04$ & $0.48 \pm 0.05$ & $0.34 \pm 0.01$ & $0.34 \pm 0.02$ & $0.32 \pm 0.02$ \\
\hline & \multicolumn{6}{|c|}{ Root Uptake Proportions from Depth } \\
\hline & RU-L1 & RU-L2 & RU-L3 & RU-L1 & RU-L2 & RU-L3 \\
\hline Jan - May & $0.76 \pm 0.02$ & $0.23 \pm 0.02$ & $0.01 \pm 0$ & $0.46 \pm 0.04$ & $0.49 \pm 0.03$ & $0.05 \pm 0.02$ \\
\hline May $1-$ June 15 & $0.76 \pm 0.04$ & $0.23 \pm 0.04$ & $0.01 \pm 0$ & $0.48 \pm 0.04$ & $0.45 \pm 0.02$ & $0.06 \pm 0.02$ \\
\hline June $16-$ Aug 1 & $0.83 \pm 0.09$ & $0.15 \pm 0.09$ & $0.02 \pm 0.01$ & $0.52 \pm 0.04$ & $0.42 \pm 0.03$ & $0.07 \pm 0.02$ \\
\hline Aug $1-$ Sept 15 & $0.88 \pm 0.1$ & $0.06 \pm 0.08$ & $0.05 \pm 0.04$ & $0.48 \pm 0.04$ & $0.44 \pm 0.02$ & $0.08 \pm 0.03$ \\
\hline \multirow[t]{3}{*}{ Sept $16-$ Oct 31} & $0.92 \pm 0.06$ & $0.04 \pm 0.02$ & $0.04 \pm 0.05$ & $0.49 \pm 0.04$ & $0.45 \pm 0.03$ & $0.06 \pm 0.02$ \\
\hline & \multicolumn{6}{|c|}{ Biomass Allocation } \\
\hline & Foliage & Stem & Roots & Foliage & Stem & Roots \\
\hline Jan - May & $0.76 \pm 0.17$ & $0.05 \pm 0.03$ & $0.2 \pm 0.15$ & \multirow{5}{*}{$0.57 \pm 0.31$} & NA & \multirow{5}{*}{$0.43 \pm 0.31$} \\
\hline May 1 - June 15 & $0.79 \pm 0.15$ & $0.03 \pm 0.02$ & $0.18 \pm 0.15$ & & NA & \\
\hline June $16-$ Aug 1 & $0.8 \pm 0.14$ & $0.03 \pm 0.02$ & $0.17 \pm 0.14$ & & NA & \\
\hline Aug $1-$ Sept 15 & $0.78 \pm 0.15$ & $0.03 \pm 0.02$ & $0.19 \pm 0.15$ & & NA & \\
\hline Sept $16-$ Oct 31 & $0.77 \pm 0.16$ & $0.03 \pm 0.02$ & $0.2 \pm 0.16$ & & NA & \\
\hline
\end{tabular}

\subsection{Evaluation of xylem water mixing}

To avoid influencing the evaluation of tree water mixing by the results of simulated soil isotopes (lower variability than measured, Fig. 3a), tree-water mixing was conducted in separate calibrations using both simulated and measured soil isotopes. Instantaneous mixing of root-uptake water throughout the tree (instant uniformity in all xylem at each time-step, as 
https://doi.org/10.5194/bg-2021-278

Preprint. Discussion started: 4 November 2021

(c) Author(s) 2021. CC BY 4.0 License.

simulated by the $\mathrm{EcH}_{2} \mathrm{O}$-iso model structure) was able to capture the general dynamics of xylem water in both willows (Fig. $6 \mathrm{a} \&$ b), though simulated day-to-day variability was limited. Unsurprisingly, the instantaneous mixing approach showed improved performance when measured soil isotopes were used rather than simulated soil isotopes, increasing seasonal and day-to-day variability (Table 4; Fig. 6c\&d). Distance-based mixing simulations of xylem water at $1 \mathrm{~m}$ were significantly better than the instant mixing simulations (lower AIC for distance-based mixing). Similar to the instant mixing simulations, the use of measured soil isotopes within the distance-based mixing approach showed improved results (AIC) compared to the use of simulated soil isotopes with the exception of the 24-hour time-step in Willow 2 (Table 4). The decrease in KGE in Willow 1 from simulated to measured data (Table 4) was an artefact of the shorter measured isotope time-series (stopping before the end of October) which did not encompass the large depletion at the end of October (time-series length incorporated in AIC).
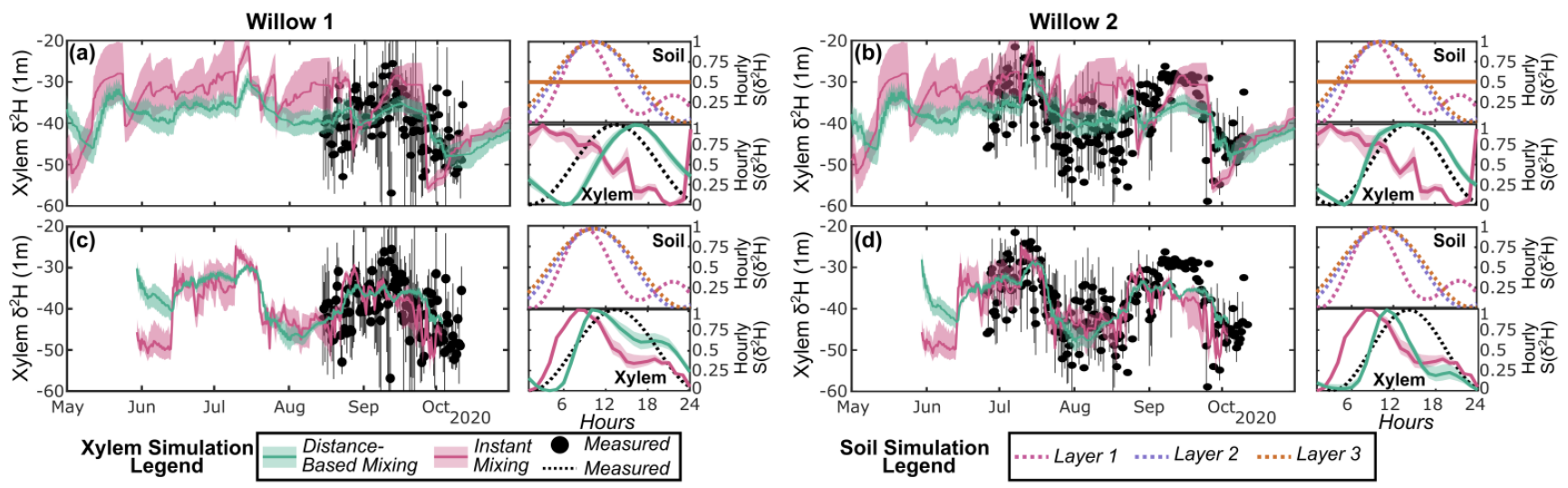

Figure 6: Simulated xylem deuterium using simulated soil deuterium with distance-based and instant mixing in (a) Willow 1, and (b) Willow 2. Simulated xylem deuterium using measured soil deuterium with distance-based and instant mixing in (c) Willow 1, and (d) Willow 2. For each simulation, standardized sub-daily $\delta^{2} H\left(S\left(\delta^{2} H\right)\right)$ shows the measured and simulated soil and xylem average hourly variability.

Xylem simulations with instant-mixing and modelled soil isotopic composition were unable to capture the observed standardized hourly variability of the xylem isotopic composition (Fig. 6a\&b). This is consistent with the limited standardized hourly variability of simulated soil isotopes relative to measured soil isotopes (Fig. 6a\&b). Distance-based simulations with modelled soil isotopes could reasonably capture the timing of sub-daily dynamics, due to the sub-daily variability of sap flow volumes. Xylem water mixing estimations using measured soil isotopes revealed a reasonable standardized hourly variability of xylem isotopes (Fig. 6c\&d). Instant mixing unsurprisingly showed dynamics similar to soil water isotopes, which peaked before the standardized measured xylem water. Distance-based mixing with measured soil isotopes was able to capture the sub-daily variability and timing of the peak; however, the rapid decrease (and late peak) in sub-daily standardized soil isotopes at $10 \mathrm{~cm}$ slightly degrades the simulated dynamics late in the day.

Model performance improved when the mixing model was calibrated to daily compared to sub-daily (6-hourly or 12-hourly) data (higher KGE). The increase in model performance is consistent with the reduced variability of measured xylem with 
https://doi.org/10.5194/bg-2021-278

Preprint. Discussion started: 4 November 2021

(c) Author(s) 2021. CC BY 4.0 License.

increasing time-steps, increasing in similarity to the variability observed in soil isotopes. Likewise, the KGE increased most rapidly with time-step on average when simulated soil isotopes were used in mixing as they lower variability than measured soil isotopes (Fig. 3).

Table 4: Akaike information criteria (AIC) and average KGE (sub-daily variability) for model performance for each willow evaluated at different time-steps. Mixing models used either output (isotope and sap flow) from $\mathrm{EcH}_{2} \mathrm{O}$-iso or measured isotope and sap flow. All models used estimated uptake proportions from $\mathrm{EcH}_{2} \mathrm{O}$-iso calibrations.

\begin{tabular}{|c|c|c|c|c|c|c|c|c|c|}
\hline \multirow{3}{*}{$\begin{array}{l}\text { Time } \\
\text { Step }\end{array}$} & \multirow{3}{*}{ Willow } & \multicolumn{4}{|c|}{$\mathrm{EcH}_{2} \mathrm{O}$-iso modelled isotope and sap flow } & \multicolumn{4}{|c|}{ Measured isotope and sap flow } \\
\hline & & \multicolumn{2}{|c|}{ Distance-Based } & \multicolumn{2}{|c|}{ Instant } & \multicolumn{2}{|c|}{ Distance-Based } & \multicolumn{2}{|l|}{ Instant } \\
\hline & & AIC & KGE & AIC & KGE & AIC & KGE & AIC & KGE \\
\hline \multirow{2}{*}{ 6hour } & 1 & 1577.7 & $0.11(0.80)$ & 1822.3 & $0.15(-0.12)$ & 1403.5 & $0(0.51)$ & 1415.4 & $0.22(0.59)$ \\
\hline & 2 & 2104.0 & $0.27(0.83)$ & 2566.8 & $0.3(-0.16)$ & 2044.3 & $0.39(0.53)$ & 2099.2 & $0.47(0.51)$ \\
\hline \multirow{2}{*}{ 12hour } & 1 & 800.3 & $0.31(0.48)$ & 951.9 & $0.12(-0.12)$ & 656.0 & $0.14(0.55)$ & 683.3 & $0.33(0.59)$ \\
\hline & 2 & 1209.2 & $0.34(0.80)$ & 1584.3 & $0.35(-0.16)$ & 1159.1 & $0.53(0.56)$ & 1236.2 & $0.54(0.51)$ \\
\hline \multirow{2}{*}{ 24hour } & 1 & 367.2 & $0.36(0.73)$ & 519.8 & $0(-0.12)$ & 314.5 & $0.36(0.61)$ & 334.4 & $0.45(0.59)$ \\
\hline & 2 & 551.2 & $0.42(0.84)$ & 900.1 & $0.41(-0.16)$ & 588.7 & $0.60(0.54)$ & 645.1 & $0.63(0.51)$ \\
\hline
\end{tabular}

\subsection{Evaluation of fluxes, uptake, and water ages through the growing season}

Differences in infiltration and percolation quantities between the willow and grass (Table 3) further propagated to water ages below each vegetation type (Fig. 7a\&b). Average layer 1 water ages below the willow (15 \pm 1 days) were similar to the grass

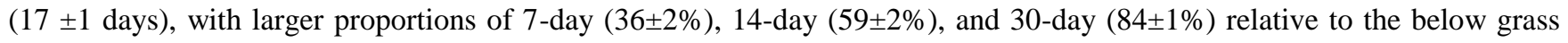
$(31 \pm 1,52 \pm 1$, and $67 \pm 1 \%$, respectively). The higher proportions of young water below the willow were primarily the result of lower moisture, causing a greater effect of infiltration on water ages. The limited percolation to layer 2 below the willow resulted in a continuously increasing water age in the deeper soil waters. Percolation throughout the summer under the grasses resulted in a stabilization of water age (average: $73 \pm 2$ days), with $81 \pm 1 \%$ of water older than 30 days. Average root water age in the root-tip was a mixture of water ages for all soil layers, with the high root uptake from shallow soils willow resulting in a younger average uptake water age in the willow roots ( $28 \pm 6$ days) compared to the more equal mixture of shallow and mid-depth soils uptaken by the grass roots resulting in older water uptake (51 \pm 3 days) (Table 3 ).

Water ages in storage and uptake were further discretized into contributions of water from each monthly precipitation 440 amount to characterize the seasonal origins of water stored and utilized. Fast turnover of water in the shallow soils (i.e. upper $10 \mathrm{~cm}$ ) resulted in low percentages of late winter and spring water (Pre- April 1) in the early growing season (13 and $18 \%$ below willow and grass, respectively, Fig. S3, Table S2\&S3), which were negligible at the end of the growing season (0 \% below willow and grass, Table S2\&S3). Limited percolation from shallow to deeper soils under the willow resulted in large proportions of deeper water originating from spring or winter precipitation (77\%), while under grass the spring and winter 445 precipitation only accounted for $37 \%$ of deeper soil water by the end of the growing season. Differences in rooting distribution and the temporal dynamics of infiltration resulted in differences of spring and winter water usage for the grass 
and willow throughout the growing season, with 33, 16, 9\% for early, mid-, and late growing season willow (57, 35, 24\%, respectively for grass) root-uptake of spring/winter water.

Willow
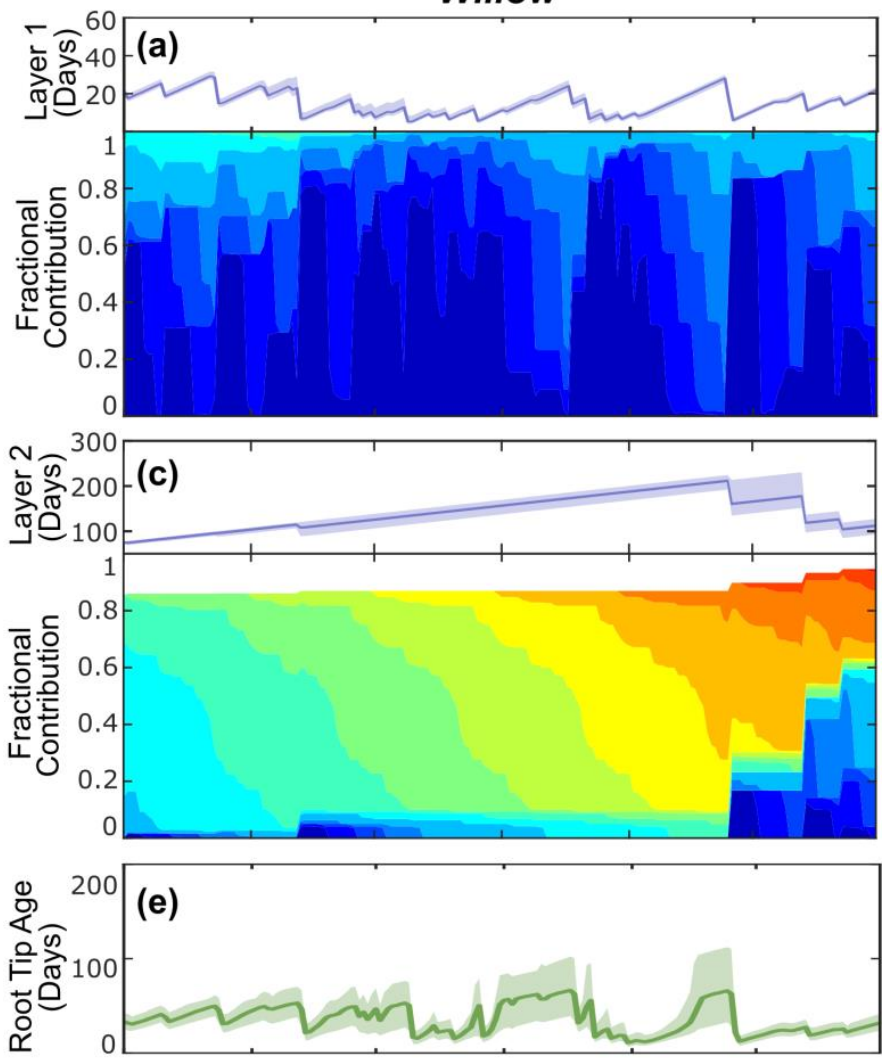

톨

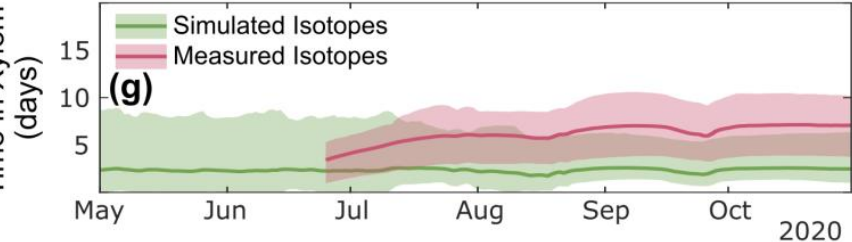

Grass
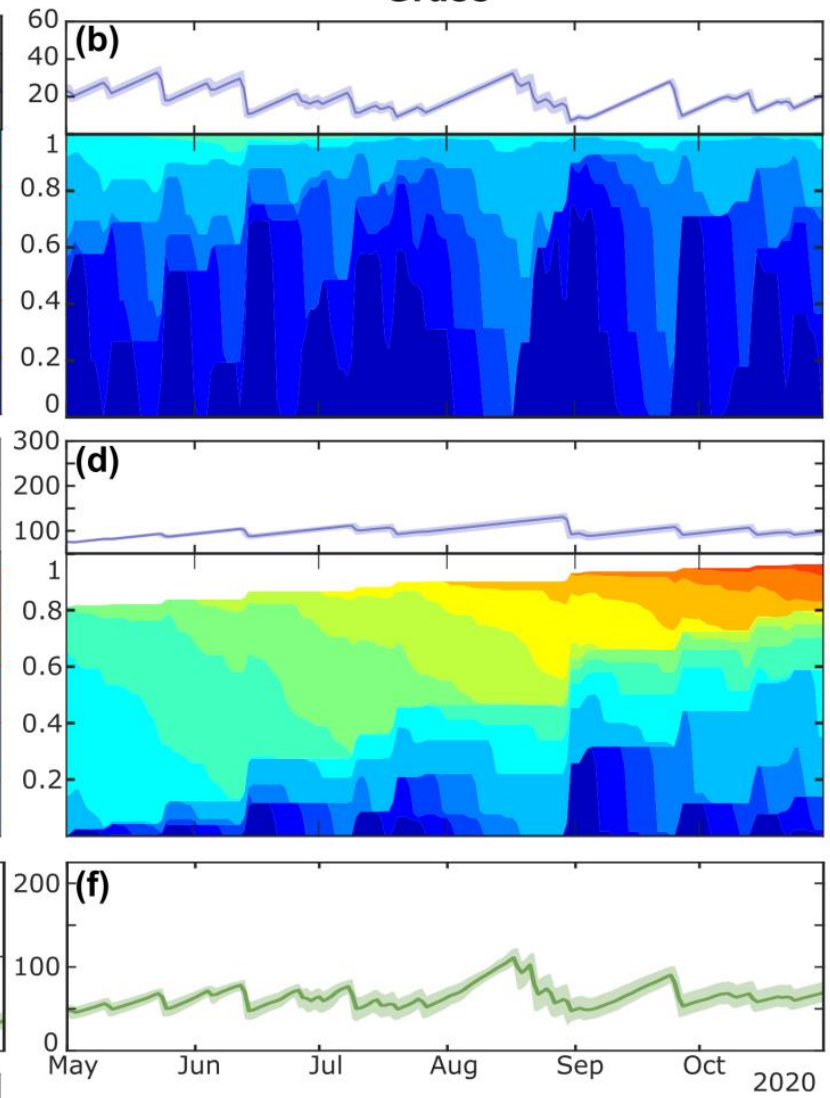

Fractional Contribution Legend

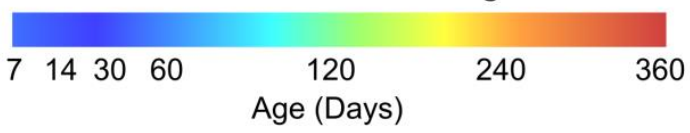

450 Figure 7: Average water age (and range) and fractional water contribution in layer 1 (10cm) in (a) willow 1 and (b) grass, in layer $2(40 \mathrm{~cm})$ in (c) willow 1 and (d) grass, average (and range) of water entering roots in (e) willow 1, and (f) grass, and (g) the average (and range) of time between root uptake and $1 \mathrm{~m}$ using distance-based mixing using simulated or measured soil isotopes.

Since instantaneous mixing has an increase of xylem water age from the roots of zero days (reaches $1 \mathrm{~m}$ instantly), xylem ages are only shown for the distance-based mixing approach (using simulated and measured soil isotopes). Using simulated soil isotopes, distance-based mixing revealed an average transit time (all time-steps) of $149 \pm 30$ hours from the roots to $1 \mathrm{~m}$ height (Fig. 7g). Distance-based xylem mixing using measured soil isotopes revealed a mean transit time of $237 \pm 97$ hours (Fig. 7g). Smaller uncertainty of transit time estimated from simulated soil and sap flow was a direct result of smaller temporal variability (lower degrees of freedom) of simulated soil isotopes compared to measured soil isotopes. 
https://doi.org/10.5194/bg-2021-278

Preprint. Discussion started: 4 November 2021

(c) Author(s) 2021. CC BY 4.0 License.

\section{(c) (i)}

\section{Discussion}

\subsection{Assessing growing season flux-storage-tracer relationships, water partitioning and biomass dynamics}

The utility of ecohydrological modelling as a tool to evaluate the linkages between water partitioning and biological dynamics is directly related to the capability of such models to accurately reproduce a wide range of variables to indicate acceptable reproduction of ecophysiological processes. At fine spatial scales, such as plot sites, reproducing flux-storagebiomass dynamics and feedback mechanisms are important as they can accentuate large-scale nonlinearities (Asbjornsen et al., 2011). Continued advancements of complex (e.g. physically-based) models and fusion with temporal high resolution, multiple data streams, can lead to the convergence of model performance for all variables (Asadzadeh et al., 2014) and higher confidence in the ability of the model to perform in across a wide range of hydroclimatic conditions. The application of a tracer-aided ecohydrological model on sub-daily time-steps using multiple data streams from intensive in-situ monitoring site provided a means to directly evaluate how well the model could simultaneously reproduce flux-storagetracer-biomass dynamics through multiple criteria throughout high variability of a growing season.

Overall, the model performed well against all measured data in both the willow and neighboring grass sites, including soil water storage, water and energy fluxes, tracer variations, and biomass dynamics throughout the growing season. Total green water usage (total ET) was notably higher for the willows compared to the grass, similar to other nearby studies (Douinot et al., 2019; Kleine et al., 2021; Smith et al., 2020b). Further, the proportions of ET for interception evaporation (as a proxy for total interception) and transpiration were well within expected ranges for both vegetation units (Coenders-Gerrits et al., 2014; Dubbert et al., 2014; Schlesinger and Jasechko, 2014; Zhou et al., 2016), including lower Tr/ET for the grass compared to the willows. This suggests adequate reproduction of water partitioning within the model. Despite the relatively dry characteristics of the soil at and below the soil moisture measurement at $10 \mathrm{~cm}$, transpiration in both willows and grass were maintained throughout the study period (Fig. 4), with only minor under-estimation of the transpiration in the willows toward the end of the growing season. This was primarily possible within $\mathrm{EcH}_{2} \mathrm{O}$-iso due to the capability of the willows using water from adjacent model cells. As observed in other nearby studies, soil evaporation contribution to ET under both the willow and grass was damped throughout the growing season due to leaf shading (LAI) causing decreased energy availability at the surface (Kleine et al., 2021; Smith et al., 2021). Although willows are generally a riparian species accessing groundwater or stream and lake water, the willows at this site did not reveal notable contribution from the deeper

485 ( $>2 \mathrm{~m})$ groundwater. The predominantly shallow root-uptake contribution (driven by higher near-surface water availability and root-distribution) was consistent with root distributions observed in willows elsewhere (Cunniff et al., 2015; Phillips et al., 2014), and only slightly lower than independent Bayesian mixing estimations conducted using soil and xylem isotopes for the same trees (Landgraf et al., 2021). The near equal contribution of shallow and mid-depth uptake in the grass (and subsequent older water age in mid-depth soils) was more prominent than the expected shallow rooting zone. The deeper 490 rooting distribution in the grass is likely due to high uptake competition in the near surface soils with the nearby high wateruse willows (Moustakas et al., 2013). Competition potentially drove deeper rooting of the grass, causing the more dynamic 
https://doi.org/10.5194/bg-2021-278

Preprint. Discussion started: 4 November 2021

(c) Author(s) 2021. CC BY 4.0 License.

\section{(c) (i)}

soil moisture at $40 \mathrm{~cm}$ as measured below the grass. The slight decrease in root biomass production in the willows during the drier summer months suggested that vegetation was not under water stress in the study period (Eziz et al., 2017). Average hourly simulated transpiration dynamics were comparable to sap flow measurements (Fig. S4), including small, but notable uptake during the night, similar to observations in other woody plants (Dawson et al., 2007).

Within this study, the relatively low soil moisture did not propagate to a notable decrease in sap flow despite a high proportion of the rooting zones in the shallow soils. While the low moisture contrasts high water usage and shallow roots of the willows, in-situ isotope dynamics were essential in confirming measurements of shallow moisture were not underrepresenting infiltration events. Multicriteria calibration using high-temporal (and highly dynamic) resolution soil isotopes revealed a strong positive correlation of simulated shallow soil moisture KGE and simulated shallow soil isotope KGE (i.e. model performance of soil isotopes only improved with performance of soil moisture). Bulk soil isotope samples, with a coarser temporal resolution, would likely have been insufficient to adequately capture the necessary isotope dynamics. $\mathrm{EcH}_{2} \mathrm{O}$-iso was only able to adequately estimate soil moisture at $10 \mathrm{~cm}$ through sub-discretization of the soils above $10 \mathrm{~cm}$, which suggested a high retention of water in soils above the measurement depth (e.g. $0-5 \mathrm{~cm})$, up-taken by roots or soil evaporation before there is sufficient water to percolate to $10 \mathrm{~cm}$. These small-scale spatial variations, as well as the large spatial differences from the soils below the willows and below the grass, and between different soil layers (Fig 3) reveal the significant heterogeneity of the site despite relatively immature soils and the local spatial scales. The heterogeneity of moisture and isotopes is likely further exacerbated by spatial heterogeneity under the canopy, as differing branch and leaf structure can impact throughfall (Dalsgaard, 2007; Gerrits et al., 2010; Li and Liang, 2019), and if such data were available,

510 it could likely further improve soil moisture simulations. In this regard it is possible that zones of higher soil moisture are present at locations below the canopy where throughfall is concentrated (Gerrits et al., 2010) which could in turn influence and increase dynamics of near surface soil water isotopic compositions.

\subsection{Evaluation of mixing dynamics of root-uptake and implications of the rooting zone}

We used output from $\mathrm{EcH}_{2} \mathrm{O}$-iso (i.e. the root-uptake sources) and a simple, parsimonious approach to further explain the

515 time-delay, and variability of xylem water from soil water. The approach showed significant improvements over the use of the instantaneous mixing currently applied within most modelling approaches. The inclusion and calibration of rooting radial distance into $\mathrm{EcH}_{2} \mathrm{O}$-iso showed comparable results to other willows ( 0.67 v. 0.5 tree height/diameter of root spread; Phillips et al. (2014)) which increases confidence in the initial estimation of spatial uptake sources. With around half of the uptake (by root length and water availability) estimated to occur outside of the willow cells, this consideration of spatial variability 520 in soil isotope composition underlines the potential influence of spatio-temporal variability of source waters on xylem isotopes, as suggested by De Deurwaerder et al. (2020) and Seeger and Weiler (2021).

As with partitioning soil moisture and vegetation water usage, high-resolution in-situ isotopes (xylem) were indispensable for constraining the mixing dynamics of root-uptake. Coarser destructive xylem sampling could potentially over-estimate xylem variability due to the large sub-daily variability, damping seasonal patterns (e.g. enrichment in September, Fig. 6) and 
https://doi.org/10.5194/bg-2021-278

Preprint. Discussion started: 4 November 2021

(c) Author(s) 2021. CC BY 4.0 License.

\section{(c) (i)}

influencing estimated root-uptake profiles. Further, while the use of tracer-aided ecohydrological model output for estimating xylem water composition with refined rooting distributions was able to reconcile general seasonal xylem dynamics and some sub-daily variability due to sap flow (Fig. 6), seasonal magnitudes of xylem isotope dynamics were predominantly due to differences in simulated v. measured soil isotopes in the shallow soils (Fig. $3 \&$ RU in Table 3). This additionally suggests the great importance of in-situ isotopic soil and vegetation measurements to constrain model estimates.

530 The use of measured data within the same framework further showed the capabilities of the approach to estimate xylem dynamics, including more direct translation of soil sub-daily variability in the xylem (Fig. 6) as suggested by von Freyberg et al. (2020). However, even the use of in-situ measured soil isotopes was unable to fully resolve the xylem dynamics with much larger day-to-day variability than could be estimated by the modelling approach (Fig. 6). Uncertainty in isotopic measurements, complex physiological processes within the trees which may cause fractionation, limitations of the model structure and interactions between these were all potentially limiting factors for reducing the xylem mixing model performance. In-situ measurement uncertainty, particularly in xylem, may be large for $\delta^{2} \mathrm{H}$ (5-10\%; Beyer et al. (2020)), greater than the standard deviation of the daily mean $\delta^{2} \mathrm{H}$ in xylem (3.7 \%). Variation in the daily mean is additionally lower than the sub-daily standard deviation $(6.8 \%$ ) which would suggest sub-daily variations are more significant than daily variations. These daily variations in xylem $\delta^{2} \mathrm{H}$ could be influenced by natural short-term climatic variability and monitoring errors, with condensation, mixing and diffusion potentially causing instabilities in measurements and greater uncertainties (Beyer et al., 2020; von Freyberg et al., 2020). In this study, condensation uncertainties were minimized by heating the tubes and were largely restricted to the autumn (September and October) when night time temperatures could be much cooler (Landgraf et al., 2021). Further, while fractionation during uptake or within vegetation has frequently been discussed and reexamined recently (Brinkmann et al., 2019; Poca et al., 2019; Vargas et al., 2017), the vegetation isotopes reflect the soil isotope sources (Fig. S5; Landgraf et al. (2021)) which suggests that vegetation specific fractionation is not likely a major cause of isotopic variation on either hourly or daily time-steps at our site. Finally, the model structure may play a role in the xylem mixing estimation, in particular with the assumed "static" transit time (consistent with the SPAC supply-demand models (Sperry et al., 2016)) limiting effects of dynamic tree cell water storage exchange with xylem. These water pools may provide a different source of contrasting isotopic composition to sap flow when transpiration is lower (De Deurwaerder

550 et al., 2020; Secchi et al., 2017) and may make a significant contribution to transpiration fluxes at certain times (Urban et al., 2014). While such a release of water may be present during peak transpiration hours, as suggested by the hourly variability of basal diameter (Fig. S6), the high water usage of willows potentially limits the proportional contribution of cell storage to xylem water.

\subsection{Implications of water ages in soil water and xylem fluxes}

555 Quantifying the age of water has significant implications for understanding how water is cycled through the critical zone, particularly for understanding the temporal changes and response times of water quantity and quality in different environments (Sprenger et al., 2019). Further discretization of average water ages into age distributions helps to illuminate 
https://doi.org/10.5194/bg-2021-278

Preprint. Discussion started: 4 November 2021

(c) Author(s) 2021. CC BY 4.0 License.

\section{(c) (i)}

how water ages are influenced by different processes (Rodriguez et al., 2020) as well as the influence of water fluxes from different temporal periods or extremes (Allen et al., 2019). The modelled contributions of different water ages in the willow root-uptake suggested that summer precipitation was the dominant source of water, accounting for $56 \%$ of total uptake (volume-weighted). This differs from other studies (e.g. Allen et al. (2019)) which have shown a higher usage of winter precipitation in leafy vegetation (beech and oak) but is consistent with estimated high contribution of recent precipitation during the growing season (Miguez-Macho and Fan, 2021). However, differences in hydroclimate, as well as variations in rooting depths between species and maturity of forests stands, likely give deeper rooting depths for beech and oak compared to shallow roots for the younger willows (in this study) which could drive differences in seasonal precipitation use by vegetation. Alternatively, the effect of separation of storage with fast and slow turnover times, or the effects of preferential flow (Sprenger and Allen, 2020), could contribute to an increase in water age if younger summer water preferentially moves through the soil or if tightly bound water is used by vegetation. However, the good temporal agreements of soil and xylem isotope samples relative to the likely dichotomy between faster and slower moving isotopes in the soil (e.g. Sprenger et al. (2019)) - implies that for the conditions present at the study site, inclusion of preferential flow or variable pore size would not influence water ages for the uptake of either in the soils. This is also consistent with the immature nature of the soils and their relatively uniform sandy nature.

Age estimates for water being transported in xylem estimated in this study were of a similar order of magnitude to estimates for other woody vegetation; averaging between 6.2 and 8.1 days with a maximum of 10.3 days at our site compared to between two days and one month in other studies (Brandes et al., 2007; Meinzer et al., 2006). While our estimates were towards the lower transit times compared to most other studies, the willows at our site were younger, had smaller diameters, and had higher xylem sap flow velocity, consistent with high water usage and low stomatal control (xylem cavitation control, Wikberg and Ögren (2007)). High-resolution in-situ measurements, capturing soil and xylem isotope dynamics were essential indispensable for improving the confidence in the estimated xylem transport age. Coarser xylem isotope samples would likely be insufficient to adequately constrain transport age uncertainty. Similar to the impact that stored tree water release can have on xylem isotopes (Section 5.2) (Brandes et al., 2007; De Deurwaerder et al., 2020); there are likely implications for water ages and identification of sources due to water released from cell storage. The effect of stored water on xylem transport ages could be significant in vegetation that utilize large fractions of previously stored water (e.g. which can be as much as $20 \%$ of transpiration; Čermák et al. (2007)). In such vegetation, total transpiration could be maintained from stored water for a week (Čermák et al., 2007) drawing water from storage cells which may be notably older than xylem water. Due to the relatively young uptake water ages of willows in this study, the inclusion of any cell water storage may significantly change the mean age of xylem water, and would increase the time period for mixing in modelling approaches, such as the one implemented here. Given the limited studies describing the ages of water and tracers in transpiring trees (Sprenger et al., 2019), more studies quantifying the transport through the xylem, as conducted here, and inclusion of

590 additional mixing within vegetation (e.g. Steppe et al. (2006)) would be beneficial to further constrain plant water use estimations. 
https://doi.org/10.5194/bg-2021-278

Preprint. Discussion started: 4 November 2021

(c) Author(s) 2021. CC BY 4.0 License.

(c) (i)

\section{Conclusion}

In order to increase understanding of the mechanisms of water cycling within the critical zone, it is essential to evaluate how water is partitioned by vegetation and the dominant processes controlling water usage and movement. Furthermore, quantifying flux and storage dynamics, through methods such as ecohydrological modelling, are necessary to understand the linkages of water in vegetation and soil at high spatial and temporal resolution. We used a large in-situ dataset under grass and willow trees, including soil moisture, energy balance, water stable isotopes, and biomass accumulation to test the capability of using a tracer-aided ecohydrological model at temporal high resolution to constrain water, energy, and isotope mass balance throughout a summer growing season. The model captured event and seasonal dynamics of soil moisture, soil and xylem water deuterium, latent and sensible heat, and biomass (stem growth). In-situ soil and vegetation isotopes were indispensable for simulating water storage, vegetation water use and source and mixing and water age estimates. Water usage at the willow plot sites showed higher evapotranspiration than grass, rapidly drying the soils down to $1 \mathrm{~m}$ with most root-uptake from upper $10 \mathrm{~cm}$. The grasses showed a greater proportion of soil evaporation in evapotranspiration compared to the willows, and root-uptake equally mixed from the upper $40 \mathrm{~cm}$. Both vegetation units showed most biomass allocated to

605 foliage growth throughout the growing season. Water age and isotopic mixing of root-uptake showed an improved estimation of xylem water stable isotopes, and the capability of the model to estimate the isotopic lag from soils in xylem. Estimated willow root-uptake showed that summer precipitation was the dominant source (56\%), with an average uptake age of 28 days (near-surface sourced water), and xylem transport time from root to $1 \mathrm{~m}$ above the surface between $6.2-8.1$ days. Such numerical modelling approaches, with a physical basis and the capability of accurate multifaceted variable estimation,

610 have a high potential for further exploration of critical zone water cycling and improved understanding of spatio-temporal changes in water availability due to vegetation-soil interactions. Continuation of integrated modelling approaches using the great value provided by in-situ data will aid future ecohydrological investigations in constraining and informing modelling, while providing high spatio-temporal resolution information of ecohydrological processes.

\section{Acknowledgements}

615 The in-situ data could be measured through equipment funded by funding by the BMBF (No: 033W034A). Funding for CS was through the project "Modelling surface and groundwater with isotopes in urban catchments" (MOSAIC) provided by the Einstein Foundation. Contributions from CS were also funded by the Leverhulme Trust's ISOLAND project. We acknowledge the IGB and Leibniz Association Open Access Publication Funds. The authors acknowledge the assistance of David Dubbert, Lukas Kleine, and Jonas Freymüller in isotope analysis and study site set-up, and Marco Maneta for discussions on EcH2O-iso modelling. 
https://doi.org/10.5194/bg-2021-278

Preprint. Discussion started: 4 November 2021

(c) Author(s) 2021. CC BY 4.0 License.

(c) (i)

\section{Code availability}

The model code of $\mathrm{EcH}_{2} \mathrm{O}$-iso is available on Bitbucket at http://bitbucket.igb-

berlin.de:7990/users/ech2o/repos/ech2o_iso/browse

\section{Data availability}

625 The data used in this study are available in the open access data base, FRED (https://fred.igb-berlin.de/data/package/582). Isotope data are password protected, with full access available from the corresponding author upon request.

\section{Author contributions}

AS conducted model set-up, calibration and validation of the $\mathrm{EcH}_{2} \mathrm{O}$-iso model mixing model utilizing earlier work led by DT, CS, MD. JL collected and conducted correction, quality control and assessment of the in-situ data. AS prepared the manuscript with contributions and editing from all co-authors.

\section{Competing interests}

The authors declare that they have no competing interests.

\section{References}

Akaike, H.: Information Theory and an Extension of the Maximum Likelihood Principle. In: Selected Papers of Hirotugu Akaike, Parzen,

635 E., Tanabe, K., and Kitagawa, G. (Eds.), Springer New York, New York, NY, 1998.

Allen, S. T. and Kirchner, J. W.: Potential effects of cryogenic extraction biases on inferences drawn from xylem water deuterium isotope ratios: case studies using stable isotopes to infer plant water sources, Hydrol. Earth Syst. Sci. Discuss., 2021, 1-15, 2021.

Allen, S. T., Kirchner, J. W., Braun, S., Siegwolf, R. T. W., and Goldsmith, G. R.: Seasonal origins of soil water used by trees, Hydrology and Earth System Sciences, 23, 1199-1210, 2019.

640 Amin, A., Zuecco, G., Geris, J., Schwendenmann, L., McDonnell, J. J., Borga, M., and Penna, D.: Depth distribution of soil water sourced by plants at the global scale: A new direct inference approach, Ecohydrology, 13, e2177, 2020.

Arya, V. K.: Introduction to Micrometeorology, Academic Press, 2001.

Asadzadeh, M., Tolson, B. A., and Burn, D. H.: A new selection metric for multiobjective hydrologic model calibration, Water Resources Research, 50, 7082-7099, 2014.

645 Asbjornsen, H., Goldsmith, G. R., Alvarado-Barrientos, M. S., Rebel, K., Van Osch, F. P., Rietkerk, M., Chen, J., Gotsch, S., Tobon, C., Geissert, D. R., Gomez-Tagle, A., Vache, K., and Dawson, T. E.: Ecohydrological advances and applications in plant-water relations research: a review, Journal of Plant Ecology, 4, 3-22, 2011.

Barbeta, A. and Peñuelas, J.: Relative contribution of groundwater to plant transpiration estimated with stable isotopes, Scientific Reports, 7, 10580, 2017.

650 Berlin, S.-. https://www.mapz.com/, last access: June 2021.

Beyer, M., Kühnhammer, K., and Dubbert, M.: In situ measurements of soil and plant water isotopes: a review of approaches, practical considerations and a vision for the future, Hydrology and Earth System Sciences, 24, 4413-4440, 2020.

Brandes, E., Wenninger, J., Koeniger, P., Schindler, D., Rennenberg, H., Leibundgut, C., Mayer, H., and Gessler, A.: Assessing environmental and physiological controls over water relations in a Scots pine (Pinus sylvestris L.) stand through analyses of stable isotope composition of water and organic matter, Plant, Cell \& Environment, 30, 113-127, 2007. 
https://doi.org/10.5194/bg-2021-278

Preprint. Discussion started: 4 November 2021

(c) Author(s) 2021. CC BY 4.0 License.

Brantley, S. L., Eissenstat, D. M., Marshall, J. A., Godsey, S. E., Balogh-Brunstad, Z., Karwan, D. L., Papuga, S. A., Roering, J., Dawson, T. E., Evaristo, J., Chadwick, O., McDonnell, J. J., and Weathers, K. C.: Reviews and syntheses: on the roles trees play in building and plumbing the critical zone, Biogeosciences, 14, 5115-5142, 2017.

Braud, I., Bariac, T., Gaudet, J. P., and Vauclin, M.: SiSPAT-Isotope, a coupled heat, water and stable isotope (HDO and H218O) transport model for bare soil. Part I. Model description and first verifications, Journal of Hydrology, 309, 277-300, 2005.

Brinkmann, N., Eugster, W., Buchmann, N., and Kahmen, A.: Species-specific differences in water uptake depth of mature temperate trees vary with water availability in the soil, Plant Biol (Stuttg), 21, 71-81, 2019.

Čermák, J., Kučera, J., Bauerle, W. L., Phillips, N., and Hinckley, T. M.: Tree water storage and its diurnal dynamics related to sap flow and changes in stem volume in old-growth Douglas-fir trees, Tree Physiology, 27, 181-198, 2007.

665 Chen, Y., Helliker, B. R., Tang, X., Li, F., Zhou, Y., and Song, X.: Stem water cryogenic extraction biases estimation in deuterium isotope composition of plant source water, Proceedings of the National Academy of Sciences, 117, 33345, 2020.

Coenders-Gerrits, A. M., van der Ent, R. J., Bogaard, T. A., Wang-Erlandsson, L., Hrachowitz, M., and Savenije, H. H.: Uncertainties in transpiration estimates, Nature, 506, E1-2, 2014.

Craig, H. and Gordon, L. I.: Deuterium and oxygen-18 variations in the ocean and the marine atmosphere. In: Stable Isotopes in

670 Oceanographic Studies and Paleotemperatures, Tongiorgi, E. (Ed.), Consiglio Nazionale della Richerche, Pisa, Italy, 1965.

Cunniff, J., Purdy, S. J., Barraclough, T. J., Castle, M., Maddison, A. L., Jones, L. E., Shield, I. F., Gregory, A. S., and Karp, A.: High yielding biomass genotypes of willow (Salix spp.) show differences in below ground biomass allocation, Biomass Bioenergy, 80, 114-127, 2015.

Dalsgaard, L.: Above and below Ground Gaps: The Effects of a Small Canopy Opening on Throughfall, Soil Moisture and Tree

675 Transpiration in Suserup Skov, Denmark, Ecological Bulletins, 52, 81-102, 2007.

Dawson, T. E., Burgess, S. S. O., Tu, K. P., Oliveira, R. S., Santiago, L. S., Fisher, J. B., Simonin, K. A., and Ambrose, A. R.: Nighttime transpiration in woody plants from contrasting ecosystems, Tree Physiology, 27, 561-575, 2007.

De Deurwaerder, H. P. T., Visser, M. D., Detto, M., Boeckx, P., Meunier, F., Kuehnhammer, K., Magh, R.-K., Marshall, J. D., Wang, L., Zhao, L., and Verbeeck, H.: Causes and consequences of pronounced variation in the isotope composition of plant xylem water,

680 Biogeosciences, 17, 4853-4870, 2020.

Deutschen Nationalkomitee, D.: http://www.stratigraphie.de/, last access: April 2021.

Douinot, A., Tetzlaff, D., Maneta, M., Kuppel, S., Schulte-Bisping, H., and Soulsby, C.: Ecohydrological modelling with EcH2O-iso to quantify forest and grassland effects on water partitioning and flux ages, Hydrological Processes, doi: 10.1002/hyp.13480, 2019. 2019.

Dubbert, M., Piayda, A., Cuntz, M., Correia, A. C., Costa, E. S. F., Pereira, J. S., and Werner, C.: Stable oxygen isotope and flux

685 partitioning demonstrates understory of an oak savanna contributes up to half of ecosystem carbon and water exchange, Front Plant Sci, 5, 530, 2014.

Dubbert, M. and Werner, C.: Water fluxes mediated by vegetation: emerging isotopic insights at the soil and atmosphere interfaces, New Phytol, 221, 1754-1763, 2019.

DWD: https://www.dwd.de/DE/klimaumwelt/cdc/cdc_node.html2021, last access: June 2021.

690 Eziz, A., Yan, Z., Tian, D., Han, W., Tang, Z., and Fang, J.: Drought effect on plant biomass allocation: A meta-analysis, Ecology and Evolution, 7, 11002-11010, 2017.

Geris, J., Tetzlaff, D., McDonnell, J. J., and Soulsby, C.: Spatial and temporal patterns of soil water storage and vegetation water use in humid northern catchments, Science of The Total Environment, 595, 486-493, 2017.

Gerrits, A. M. J., Pfister, L., and Savenije, H. H. G.: Spatial and temporal variability of canopy and forest floor interception in a beech

695 forest, Hydrological Processes, 24, 3011-3025, 2010.

Gessler, A., Bachli, L., Rouholahnejad Freund, E., Treydte, K., Schaub, M., Haeni, M., Weiler, M., Seeger, S., Marshall, J., Hug, C., Zweifel, R., Hagedorn, F., Rigling, A., Saurer, M., and Meusburger, K.: Drought reduces water uptake in beech from the drying topsoil, but no compensatory uptake occurs from deeper soil layers, New Phytol, doi: 10.1111/nph.17767, 2021. 2021.

Gillefalk, M., Tetzlaff, D., Hinkelmann, R., Kuhlemann, L.-M., Smith, A., Meier, F., Maneta, M. P., and Soulsby, C.: Quantifying the

700 effects of urban green space on water partitioning and ages using an isotope-based ecohydrological model, Hydrology and Earth System Sciences, 25, 3635-3652, 2021.

Goldsmith, G. R., Allen, S. T., Braun, S., Engbersen, N., González-Quijano, C. R., Kirchner, J. W., and Siegwolf, R. T. W.: Spatial variation in throughfall, soil, and plant water isotopes in a temperate forest, Ecohydrology, doi: 10.1002/eco.2059, 2018. 2018.

Good, S. P., Noone, D., and Bowen, G.: Hydrologic connectivity constrains partitioning of global terrestrial water fluxes, Science, 349,

$705175,2015$.

Grant, G. E. and Dietrich, W. E.: The frontier beneath our feet, Water Resources Research, 53, 2605-2609, 2017.

Gudmundsson, L., Leonard, M., Do, H. X., Westra, S., and Seneviratne, S. I.: Observed Trends in Global Indicators of Mean and Extreme Streamflow, Geophysical Research Letters, 46, 756-766, 2019.

Hersbach, H., Bell, B., Berrisford, P., Hirahara, S., Horányi, A., Muñoz-Sabater, J., Nicolas, J., Peubey, C., Radu, R., Schepers, D., 710 Simmons, A., Soci, C., Abdalla, S., Abellan, X., Balsamo, G., Bechtold, P., Biavati, G., Bidlot, J., Bonavita, M., De Chiara, G., Dahlgren, P., Dee, D., Diamantakis, M., Dragani, R., Flemming, J., Forbes, R., Fuentes, M., Geer, A., Haimberger, L., Healy, S., Hogan, R. J., Hólm, 
https://doi.org/10.5194/bg-2021-278

Preprint. Discussion started: 4 November 2021

(c) Author(s) 2021. CC BY 4.0 License.

E., Janisková, M., Keeley, S., Laloyaux, P., Lopez, P., Lupu, C., Radnoti, G., de Rosnay, P., Rozum, I., Vamborg, F., Villaume, S., and Thépaut, J.-N.: The ERA5 global reanalysis, Quarterly Journal of the Royal Meteorological Society, 146, 1999-2049, 2020.

Isebrands, J. G. and Richardson, J.: Poplars and willows: trees for society and the environment, The Food and Agriculture Organization of the United Nations \& CABI, 2014.

Jasechko, S., Sharp, Z. D., Gibson, J. J., Birks, S. J., Yi, Y., and Fawcett, P. J.: Terrestrial water fluxes dominated by transpiration, Nature, 496, 347-350, 2013.

Jones, H. G. and Tardieu, F.: Modelling water relations of horticultural crops: a review, Scientia Horticulturae, 74, 21 -46, 1998.

Kleine, L., Tetzlaff, D., Smith, A., Dubbert, M., and Soulsby, C.: Modelling ecohydrological feedbacks in forest and grassland plots under

720 a prolonged drought anomaly in central Europe 2018-2020, Hydrological Processes, n/a, e14325, 2021.

Kling, H., Fuchs, M., and Paulin, M.: Runoff conditions in the upper Danube basin under an ensemble of climate change scenarios, Journal of Hydrology, 424-425, 264-277, 2012.

Knighton, J., Kuppel, S., Smith, A., Soulsby, C., Sprenger, M., and Tetzlaff, D.: Using isotopes to incorporate tree water storage and mixing dynamics into a distributed ecohydrologic modelling framework, Ecohydrology, 13, 2020.

725 Kool, D., Agam, N., Lazarovitch, N., Heitman, J. L., Sauer, T. J., and Ben-Gal, A.: A review of approaches for evapotranspiration partitioning, Agricultural and Forest Meteorology, 184, 56-70, 2014.

Kuppel, S., Tetzlaff, D., Maneta, M. P., and Soulsby, C.: EcH2O-iso 1.0: water isotopes and age tracking in a process-based, distributed ecohydrological model, Geoscientific Model Development, 11, 3045-3069, 2018a.

Kuppel, S., Tetzlaff, D., Maneta, M. P., and Soulsby, C.: What can we learn from multi-data calibration of a process-based 730 ecohydrological model?, Environmental Modelling \& Software, 101, 301-316, 2018b.

Landgraf, J., Tetzlaff, D., Dubbert, M., Smith, A., and Soulsby, C.: Xylem water in riparian Willow trees (Salix alba) reveals shallow sources of root water uptake by in-situ monitoring of stable water isotopes in soil and tree water, Hydrol. Earth Syst. Sci. Discuss., 2021. 2021.

Lee, T. and Pielke, R. A.: Estimating the Soil Surface Specific Humidity, Journal of Applied Meteorology, 31, 480-484, 1992.

735 Li, S.-L. and Liang, W.-L.: Spatial-Temporal Soil Water Dynamics beneath a Tree Monitored by Tensiometer-Time Domain Reflectometry Probes, Water, 11, 2019.

Lobell, D. B. and Gourdji, S. M.: The influence of climate change on global crop productivity, Plant Physiol, 160, 1686-1697, 2012.

Lobell, D. B., Schlenker, W., and Costa-Roberts, J.: Climate Trends and Global Crop Production Since 1980, Science, 333, 616, 2011.

Maneta, M. P. and Silverman, N. L.: A Spatially Distributed Model to Simulate Water, Energy, and Vegetation Dynamics Using

740 Information from Regional Climate Models, Earth Interactions, 17, 1-44, 2013.

Marshall, J. D., Cuntz, M., Beyer, M., Dubbert, M., and Kuehnhammer, K.: Borehole Equilibration: Testing a New Method to Monitor the Isotopic Composition of Tree Xylem Water in situ, Front Plant Sci, 11, 358, 2020.

Meinzer, F. C., Brooks, J. R., Domec, J. C., Gartner, B. L., Warren, J. M., Woodruff, D. R., Bible, K., and Shaw, D. C.: Dynamics of water transport and storage in conifers studied with deuterium and heat tracing techniques, Plant, Cell \& Environment, 29, $105-114,2006$.

745 Miguez-Macho, G. and Fan, Y.: Spatiotemporal origin of soil water taken up by vegetation, Nature, doi: 10.1038/s41586-021-03958-6, 2021. 2021.

Moustakas, A., Kunin, W. E., Cameron, T. C., and Sankaran, M.: Facilitation or competition? Tree effects on grass biomass across a precipitation gradient, PLoS One, 8, e57025, 2013.

Myneni, R., Knyazikhin, Y., and Park, T.: 2021.

750 Oerter, E. J. and Bowen, G.: In situ monitoring of $\mathrm{H}$ and $\mathrm{O}$ stable isotopes in soil water reveals ecohydrologic dynamics in managed soil systems, Ecohydrology, 10, e1841, 2017.

Ogle, K., Tucker, C., and Cable, J. M.: Beyond simple linear mixing models: process-based isotope partitioning of ecological processes, Ecological Applications, 24, 181-195, 2014.

Oki, T. and Kanae, S.: Global Hydrological Cycles and World Water Resources, Science, 313, 1068, 2006.

755 Penna, D., Hopp, L., Scandellari, F., Allen, S. T., Benettin, P., Beyer, M., Geris, J., Klaus, J., Marshall, J. D., Schwendenmann, L., Volkmann, T. H. M., von Freyberg, J., Amin, A., Ceperley, N., Engel, M., Frentress, J., Giambastiani, Y., McDonnell, J. J., Zuecco, G., Llorens, P., Siegwolf, R. T. W., Dawson, T. E., and Kirchner, J. W.: Ideas and perspectives: Tracing terrestrial ecosystem water fluxes using hydrogen and oxygen stable isotopes - challenges and opportunities from an interdisciplinary perspective, Biogeosciences, 15, 6399$6415,2018$.

760 Phillips, C. J., Marden, M., and Suzanne, L. M.: Observations of root growth of young poplar and willow planting types, New Zealand Journal of Forestry Science, 44, 15, 2014.

Poca, M., Coomans, O., Urcelay, C., Zeballos, S. R., Bodé, S., and Boeckx, P.: Isotope fractionation during root water uptake by Acacia caven is enhanced by arbuscular mycorrhizas, Plant and Soil, 441, 485-497, 2019.

Rodriguez, N. B., Benettin, P., and Klaus, J.: Multimodal water age distributions and the challenge of complex hydrological landscapes,

765 Hydrological Processes, 34, 2707-2724, 2020.

Rothfuss, Y. and Javaux, M.: Reviews and syntheses: Isotopic approaches to quantify root water uptake: a review and comparison of methods, Biogeosciences, 14, 2199-2224, 2017. 
https://doi.org/10.5194/bg-2021-278

Preprint. Discussion started: 4 November 2021

(c) Author(s) 2021. CC BY 4.0 License.

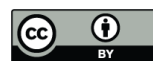

Schlesinger, W. H. and Jasechko, S.: Transpiration in the global water cycle, Agricultural and Forest Meteorology, 189-190, 115-117, 2014.

770 Secchi, F., Pagliarani, C., and Zwieniecki, M. A.: The functional role of xylem parenchyma cells and aquaporins during recovery from severe water stress, Plant Cell Environ, 40, 858-871, 2017.

Seeger, S. and Weiler, M.: Temporal dynamics of tree xylem water isotopes: In-situ monitoring and modelling Biogeosciences Discuss, doi: 10.5194/bg-2021-35, 2021. 2021.

Smith, A., Tetzlaff, D., Gelbrecht, J., Kleine, L., and Soulsby, C.: Riparian wetland rehabilitation and beaver re-colonization impacts on

775 hydrological processes and water quality in a lowland agricultural catchment, Sci Total Environ, 699, 134302, 2020a.

Smith, A., Tetzlaff, D., Kleine, L., Maneta, M., and Soulsby, C.: Quantifying the effects of land use and model scale on water partitioning and water ages using tracer-aided ecohydrological models, Hydrology and Earth System Sciences, 25, 2239-2259, 2021.

Smith, A., Tetzlaff, D., Kleine, L., Maneta, M. P., and Soulsby, C.: Isotope-aided modelling of ecohydrologic fluxes and water ages under mixed land use in Central Europe: The 2018 drought and its recovery, Hydrological Processes, 34, 3406-3425, 2020b.

780 Sperry, J. S. and Love, D. M.: What plant hydraulics can tell us about responses to climate-change droughts, New Phytol, 207, 14-27, 2015.

Sperry, J. S., Wang, Y., Wolfe, B. T., Mackay, D. S., Anderegg, W. R., McDowell, N. G., and Pockman, W. T.: Pragmatic hydraulic theory predicts stomatal responses to climatic water deficits, New Phytol, 212, 577-589, 2016.

Sprenger, M. and Allen, S. T.: What Ecohydrologic Separation Is and Where We Can Go With It, Water Resources Research, 56,

785 e2020WR027238, 2020.

Sprenger, M., Stumpp, C., Weiler, M., Aeschbach, W., Allen, S. T., Benettin, P., Dubbert, M., Hartmann, A., Hrachowitz, M., Kirchner, J. W., McDonnell, J. J., Orlowski, N., Penna, D., Pfahl, S., Rinderer, M., Rodriguez, N., Schmidt, M., and Werner, C.: The Demographics of Water: A Review of Water Ages in the Critical Zone, Reviews of Geophysics, 57, 800-834, 2019.

Steppe, K., De Pauw, D. J. W., Lemeur, R., and Vanrolleghem, P. A.: A mathematical model linking tree sap flow dynamics to daily stem diameter fluctuations and radial stem growth, Tree Physiology, 26, 257-273, 2006.

Sutanto, S. J., Wenninger, J., Coenders-Gerrits, A. M. J., and Uhlenbrook, S.: Partitioning of evaporation into transpiration, soil evaporation and interception: a comparison between isotope measurements and a HYDRUS-1D model, Hydrology and Earth System Sciences, 16, 2605-2616, 2012.

Taylor, R. G., Scanlon, B., Döll, P., Rodell, M., van Beek, R., Wada, Y., Longuevergne, L., Leblanc, M., Famiglietti, J. S., Edmunds, M.,

795 Konikow, L., Green, T. R., Chen, J., Taniguchi, M., Bierkens, M. F. P., MacDonald, A., Fan, Y., Maxwell, R. M., Yechieli, Y., Gurdak, J. J., Allen, D. M., Shamsudduha, M., Hiscock, K., Yeh, P. J. F., Holman, I., and Treidel, H.: Ground water and climate change, Nature Climate Change, 3, 322-329, 2013.

Tetzlaff, D., Buttle, J., Carey, S. K., Kohn, M. J., Laudon, H., McNamara, J. P., Smith, A., Sprenger, M., and Soulsby, C.: Stable isotopes of water reveal differences in plant - soil water relationships across northern environments, Hydrological Processes, $35,2021$.

800 UFZ: https://www.ufz.de/index.php?en=41160, last access: April 2021.

Urban, J., Čermák, J., and Ceulemans, R.: Above- and below-ground biomass, surface and volume, and stored water in a mature Scots pine stand, European Journal of Forest Research, 134, 61-74, 2014.

Vargas, A. I., Schaffer, B., Yuhong, L., and Sternberg, L.: Testing plant use of mobile vs immobile soil water sources using stable isotope experiments, New Phytol, 215, 582-594, 2017.

805 von Freyberg, J., Allen, S. T., Grossiord, C., Dawson, T. E., and Royles, J.: Plant and root-zone water isotopes are difficult to measure, explain, and predict: Some practical recommendations for determining plant water sources, Methods in Ecology and Evolution, 11, 1352$1367,2020$.

Wikberg, J. and Ögren, E.: Variation in drought resistance, drought acclimation and water conservation in four willow cultivars used for biomass production, Tree Physiology, 27, 1339-1346, 2007.

810 Xiao, W., Wei, Z., and Wen, X.: Evapotranspiration partitioning at the ecosystem scale using the stable isotope method-A review, Agricultural and Forest Meteorology, 263, 346-361, 2018.

Zhang, Y., Pena-Arancibia, J. L., McVicar, T. R., Chiew, F. H., Vaze, J., Liu, C., Lu, X., Zheng, H., Wang, Y., Liu, Y. Y., Miralles, D. G., and Pan, M.: Multi-decadal trends in global terrestrial evapotranspiration and its components, Sci Rep, 6, $19124,2016$.

Zhou, S., Yu, B., Zhang, Y., Huang, Y., and Wang, G.: Partitioning evapotranspiration based on the concept of underlying water use efficiency, Water Resources Research, 52, 1160-1175, 2016. 